\title{
Size-resolved observations of refractory black carbon particles in cloud droplets at a marine boundary layer site
}

\author{
J. C. Schroder ${ }^{1}$, S. J. Hanna ${ }^{1}$, R. L. Modini ${ }^{2}$, A. L. Corrigan $^{2}$, S. M. Kreidenwies ${ }^{6}$, A. M. Macdonald ${ }^{3}$, K. J. Noone ${ }^{5}$, \\ L. M. Russell ${ }^{2}$, W. R. Leaitch ${ }^{4}$, and A. K. Bertram ${ }^{1}$ \\ ${ }^{1}$ Department of Chemistry, University of British Columbia, Vancouver, BC, V6T 1Z1, Canada \\ ${ }^{2}$ Scripps Institute of Oceanography, University of California-San Diego, La Jolla, San Diego, CA, USA \\ ${ }^{3}$ Air Quality Processes Research Section, Environment Canada, Toronto, ON, Canada \\ ${ }^{4}$ Climate Chemistry and Measurements Research, Environment Canada, Toronto, ON, Canada \\ ${ }^{5}$ Department of Applied Environmental Science, Stockholm University, Stockholm, Sweden \\ ${ }^{6}$ Department of Atmospheric Science, Colorado State University, Fort Collins, CO, USA
}

Correspondence to: A. Bertram (bertram@chem.ubc.ca)

Received: 4 April 2014 - Published in Atmos. Chem. Phys. Discuss.: 7 May 2014

Revised: 27 November 2014 - Accepted: 3 January 2015 - Published: 9 February 2015

\begin{abstract}
Size-resolved observations of aerosol particles and cloud droplet residuals were studied at a marine boundary layer site (251 m a.m.s.1.) in La Jolla, San Diego, California, during 2012. A counterflow virtual impactor (CVI) was used as the inlet to sample cloud residuals while a total inlet was used to sample both cloud residuals and interstitial particles. Two cloud events totaling $10 \mathrm{~h}$ of in-cloud sampling were analyzed. Based on bulk aerosol particle concentrations, mass concentrations of refractory black carbon ( $\mathrm{rBC})$, and back trajectories, the two air masses sampled were classified as polluted marine air. Since the fraction of cloud droplets sampled by the CVI was less than $100 \%$, the measured activated fractions of $\mathrm{rBC}$ should be considered as lower limits to the total fraction of $\mathrm{rBC}$ activated during the two cloud events. Size distributions of $\mathrm{rBC}$ and a coating analysis showed that sub-100 nm rBC cores with relatively thick coatings were incorporated into the cloud droplets (i.e., $95 \mathrm{~nm}$ rBC cores with median coating thicknesses of at least $65 \mathrm{~nm}$ were incorporated into the cloud droplets). Measurements also show that the coating volume fraction of $\mathrm{rBC}$ cores is relatively large for sub-100 nm rBC cores. For example, the median coating volume fraction of $95 \mathrm{~nm} \mathrm{rBC}$ cores incorporated into cloud droplets was at least 0.9 , a result that is consistent with $\kappa$-Köhler theory. Measurements of the total diameter of the $\mathrm{rBC}$-containing particles ( $\mathrm{rBC}$ core and coating) suggest that the total diameter of $\mathrm{rBC}$-containing particles needed to be at least $165 \mathrm{~nm}$ to be incorporated into cloud droplets when
\end{abstract}

the core $\mathrm{rBC}$ diameter is $\geq 85 \mathrm{~nm}$. This result is consistent with previous work that has shown that particle diameter is important for activation of non-rBC particles. The activated fractions of $\mathrm{rBC}$ determined from the measurements ranged from 0.01 to 0.1 for core $\mathrm{rBC}$ diameters ranging from 70 to $220 \mathrm{~nm}$. This type of data is useful for constraining models used for predicting $\mathrm{rBC}$ concentrations in the atmosphere.

\section{Introduction}

Black carbon (BC) is a subset of the aerosol population that is emitted as a result of incomplete combustion. Since BC particles strongly absorb solar radiation, they can modify the climate directly. Based on the current best-estimates the $\mathrm{BC}$ direct radiative forcing from all present-day sources is $+0.88 \mathrm{~W} \mathrm{~m}^{-2}$; however, the uncertainty associated with this number is approximately $90 \%$. The uncertainty in the BC direct radiative forcing estimates stems from several factors which include the removal rates of $\mathrm{BC}$ from the atmosphere through wet or dry deposition (Bond et al., 2013). BC particles can also potentially act as cloud condensation nuclei (CCN) and contribute to the indirect effects of aerosols on climate (Bond et al., 2013). The current best estimates of the indirect radiative forcing of $\mathrm{BC}$ is $+0.23 \mathrm{~W} \mathrm{~m}^{-2}$ (Bond et al., 2013). However, similar to the direct radiative forcing estimate, this indirect radiative forcing estimate is also 
highly uncertain, with an uncertainty of approximately $90 \%$ (Bond et al., 2013). The uncertainty in the indirect effect radiative forcing estimate is partially due to an uncertainty in BC-cloud interactions (Bond et al., 2013). To better understand the direct and indirect effects of $\mathrm{BC}$ on climate, a better understanding of the activation of $\mathrm{BC}$ into cloud droplets is needed.

Despite the importance of activation of $\mathrm{BC}$ particles into cloud droplets, there have only been a small number of studies that have investigated the activation of $\mathrm{BC}$ particles into cloud droplets under real atmospheric conditions (see Table 1 in Cozic et al., 2007, as well as Pratt et al., 2010, and Granat et al., 2010). Of these studies, most have been carried out at mid- to high-altitude mountain sites (Cozic et al., 2007; Hitzenberger et al., 2000, 2001; Kasper-Giebl et al., 2000; Sellegri et al., 2003). Only a few studies have investigated the activation of $\mathrm{BC}$ particles at marine or coastal sites (Gieray et al., 1997; Granat et al., 2010). In addition, almost all of the previous studies have focused on the fraction of total BC mass activated into cloud droplets. For example, Hallberg et al. (1992) measured the mass scavenging of BC into fog droplets at a polluted site in the Po Valley (Italy). They found that the mass fraction of scavenged BC $(0.06)$ was statistically smaller than the scavenged fraction of sulfate $(0.18)$. Similar results were obtained when sampling stratocumulus clouds at a mountaintop site at Kleiner Feldberg, Germany. There, a statistically significant difference in scavenging was also observed; the scavenged fraction of sulfate at this site was 0.52 while the scavenged fraction of $\mathrm{BC}$ was 0.15 (Hallberg et al., 1994). In this latter case, observations showed that $\mathrm{BC}$ particles found as cloud droplet residuals were of mixed composition, often having a water-soluble component that varied as a function of size. These studies reporting mass scavenging of $\mathrm{BC}$ can be useful for validating models. However, since the CCN properties of refractory black carbon (rBC)-containing particles are more closely linked to number and particle size, the studies that focus on BC mass scavenging are unable to determine the relative contribution of particle size and composition to the activation of $\mathrm{BC}$ into clouds.

Recent studies have compared concentrations of $\mathrm{BC}$ particles measured over the central Pacific from $85^{\circ} \mathrm{N}$ to $67^{\circ} \mathrm{S}$ during the HIAPER (High-Performance Instrumented Airborne Platform for Environmental Research) Pole-to-Pole Observations (HIPPO) campaign, with predictions using a global chemical transport model (Wang et al., 2014). The authors concluded that most models may not be accurately simulating the scavenging of $\mathrm{BC}$ particles into cloud droplets (Wang et al., 2014). To help better constrain these models, additional studies on the activation of BC into cloud droplets under real atmospheric conditions and at different locations and times would be helpful.

The single particle soot photometer (SP2) is an instrument recently developed to determine the refractory black carbon (rBC) mass of individual particles (Moteki and Kondo, 2007; Schwarz et al., 2006; Stephens et al., 2003). With this instru- ment, size distributions of $\mathrm{rBC}$ can be obtained in real time. In addition, this instrument provides information on coating thicknesses of the rBC-containing particles. The SP2 has now been used extensively to determine the size distribution and coating thicknesses of $\mathrm{rBC}$ particles in the atmosphere. Here, we apply this technique to investigate the activation of rBC particles in stratocumulus clouds at a marine boundary layer site. Specific questions to be addressed include the following: (1) what is the activated fraction of $\mathrm{rBC}$ as a function of particle size in the marine stratocumulus clouds studied? (2) Do small (sub-100 nm) rBC cores get incorporated into the cloud droplets? (3) What is the thickness of the coating on the $\mathrm{rBC}$ cores that are incorporated into the cloud droplets? (4) Is the $\mathrm{rBC}$ coating volume fraction and the total diameter ( $\mathrm{rBC}$ core and coating thickness) important for activation of rBC into cloud droplets? (5) Are the results consistent with $\kappa$-Köhler theory, which is used in advanced modeling studies to describe the activation of $\mathrm{rBC}$ particles into cloud droplets (e.g., Fierce et al., 2013; Riemer et al., 2010)?

\section{Site, sampling and analysis}

\subsection{Site description}

The sampling site was located below the peak of Mt. Soledad (251 m a.m.s.l.) which is $\sim 2 \mathrm{~km}$ from the coast of the Pacific Ocean in La Jolla, CA $\left(32.8400^{\circ} \mathrm{N}, 117.2769^{\circ} \mathrm{W}\right)$ and has mostly light commercial and residential activities in the area. The cloud periods occurred primarily at night when these activities are at a minimum. The city of La Jolla is predominately residential with a population of approximately 43000 people and is situated $24 \mathrm{~km}$ north of San Diego (population 1.3 million), the closest urban center (Zhao et al., 2014).

Data was collected from 27 May to 18 June 2012 using instruments housed in a modified shipping container. A total of three stratocumulus cloud events were sampled during this time frame. The first cloud event was excluded from this analysis due to an instrumental error. The second cloud event occurred from 12 June 2012, 20:43 to 13 June 2012, 11:35 PDT, and is hereinafter called Cloud 2. The third cloud event took place from 17 June 2012, 20:36 to 18 June 2012, 07:52 PDT, and is called Cloud 3 for the remainder of the document.

\subsection{Inlets}

Two inlets, referred to as the total inlet and residual inlet, were used during this study (Fig. 1). The total inlet measured both interstitial and cloud residual particles during cloud events. This heated inlet was designed and built following the specifications reported by Bates et al. (2002) and therefore assumed to have the same transmission efficiency, namely $>95 \%$ for particles less than $6.5 \mu \mathrm{m}$, using a $\sim 900 \mathrm{Lpm}$ bypass flow. The instruments sampling from the plenum of the total inlet (Fig. 1) were connected sequentially to a common 


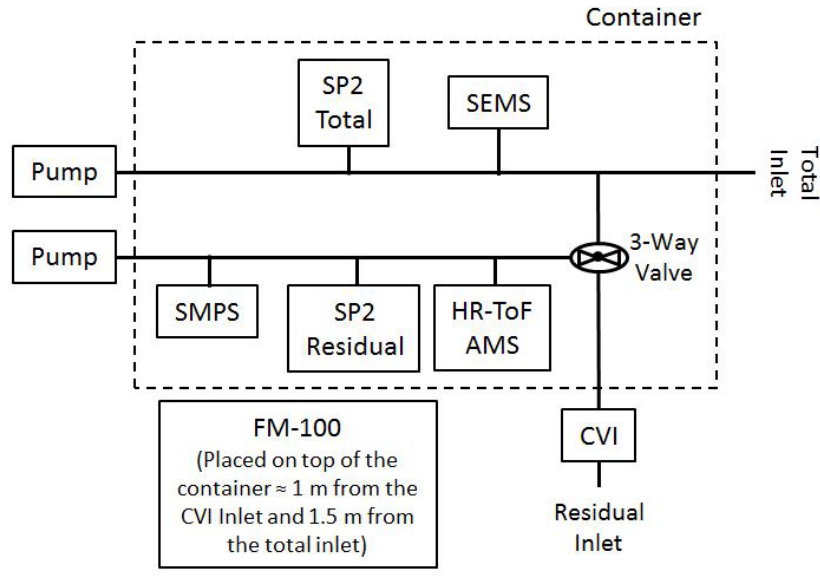

Figure 1. Schematic showing the configuration of the inlets and instrumentation housed in the shipping container.

sampling line ( 0.25 in. stainless steel tubing). A pump was placed at the end of this sampling line creating a bypass flow of $\sim 2 \mathrm{Lpm}$.

The intake of the residual inlet was a counterflow virtual impactor (CVI, see Sect. 2.3 and Sect. S1 in the Supplement) that enabled the sampling of cloud droplets without contamination from interstitial particles, or ambient gases, thus only the residual particles of the cloud droplets were sampled. This inlet was used only during cloudy periods and was connected to a branch of the total inlet by a three-way valve (Fig. 1). During a cloud event, the valve was manually switched so that cloud droplets were sampled through the CVI and cloud residuals were measured by instrumentation connected downstream of the valve. At times when no clouds were present the valve was switched such that all instruments were sampling ambient particles. All instruments downstream of the three-way valve were sequentially connected to a common sampling line $(0.25 \mathrm{in}$. stainless steel tubing). A pump was also placed at the end of the sampling line creating a bypass flow of $\sim 2 \mathrm{Lpm}$.

Since much of the analysis used in this paper is based on a measured ratio of particle number concentrations it was necessary to ensure that there were no significant losses of particles due to the inlet configurations. Therefore, particle losses from diffusion, sedimentation, turbulent inertial deposition and inertial deposition from both bends and contractions for the total and residual inlets (assuming cloud-free sampling) were calculated using the Particle Loss Calculator (Von der Weiden et al., 2009) and found to be $<2 \%$ for particles with diameters between 0.07 and $1 \mu \mathrm{m}$, covering the size range used for this analysis.

\subsection{Counterflow virtual impactor sampling}

The CVI was based on the design of Noone et al. (1988), where droplet-laden air was drawn into the CVI using a high velocity air intake vacuum $\left(\approx 92 \mathrm{~m} \mathrm{~s}^{-1}\right)$. Only those droplets with enough inertia to overcome a counterflow of zero air with an average flow rate of $\approx 5 \mathrm{Lpm}$ made it past the region known as the stagnation plane and were entrained into the sample flow and transported to the instruments downstream. Water from these droplets began evaporating upon impact with the warm dry counterflow air, held at a constant temperature of $40^{\circ} \mathrm{C}$, and particles were further dried by a heated section of the sampling tube, also at $40^{\circ} \mathrm{C}$, leaving only the droplet residuals to be sampled downstream. If the droplets were completely evaporated, any volatile gases in the cloud droplets, such as nitric acid, likely evaporated and were not part of the residual particles (Zhao et al., 2014). If some water was retained by the residual particles at this temperature, a fraction of highly soluble volatile components may have also remained.

The smallest droplet diameter for which $50 \%$ of the droplets are sampled is considered to be the CVI cut-size (CVI- $D_{50}$ ) and is the diameter for which a droplet's stopping distance is greater than the CVI inlet diameter and the length to the end of the stagnation plane (Anderson et al., 1993; Noone et al., 1988). For the clouds sampled in this study, a CVI- $D_{50}$ of $11.5 \pm 0.7 \mu \mathrm{m}$ and $11.6 \pm 0.7 \mu \mathrm{m}$ for Cloud 2 and Cloud 3, respectively, were calculated (Sect. S1).

Due to the properties of a CVI, particle concentrations are enhanced at the exit of the CVI compared to ambient conditions. Enhancement factors (EF) of 7.1 and 7.4 for Cloud 2 and Cloud 3, respectively, were calculated based on the flow rates used during sampling (Sect. S1).

\subsection{Black carbon measurements}

Refractory black carbon (rBC) was measured from the total inlet and the residual inlet using two separate single particle soot photometers (SP2, DMT, Boulder, CO). These instruments are referred to as the total SP2 (SP2 ${ }_{\mathrm{Tot}}$ ) and the residual SP2 (SP2 Res). The location of these instruments is shown in Fig. 1. The SP2 has been described in detail elsewhere (Moteki and Kondo, 2007; Schwarz et al., 2006; Stephens et al., 2003). Briefly, particles are sampled at $\approx 0.12 \mathrm{Lpm}$ and carried directly into a chamber housing a high intensity $\left(\approx 1 \mathrm{MW} \mathrm{cm}^{-2}\right)$ intra-cavity $\mathrm{Nd}$ : YAG laser operating at $\lambda=1064 \mathrm{~nm}$. BC particles are rapidly heated, through absorption, to incandescence, where the emitted visible light is detected by two photomultipliers. The mass of individual $\mathrm{rBC}$ particles can be determined using a calibration plot, where the amplitude of the detector response is proportional to the mass of a reference material. The two SP2s used in this study were calibrated pre and post-campaign with Aquadag ${ }^{\circledR}$ (Moteki et al., 2009), using effective densities reported by Gysel et al. (2011). Based on the recommendations by Baumgardner et al. (2012), the average peak heights determined for each of the Aquadag ${ }^{\circledR}$ sizes were scaled downward by 0.75 since Aquadag ${ }^{\circledR}$ has been shown to cause a higher SP2 signal response per unit mass than ambient $\mathrm{BC}$. 
The calibration parameters used to determine mass were taken from a linear fit of the combined pre and post-campaign data. The uncertainty in the rBC mass (at the $95 \%$ confidence limit) stemming from uncertainty in the fit of the calibration was $1-16 \%$ for SP2 $2_{\text {Res }}$ (depending on particle mass) and $3-25 \%$ for SP2 ${ }_{\text {Tot }}$ (depending on particle mass). A volume equivalent diameter was also determined from the measured mass assuming a black carbon density of $1.8 \mathrm{~g} \mathrm{~cm}^{-3}$ (Bond and Bergstrom, 2006). The SP2 Res was a four-channel instrument with a detection range of approximately 70 to $220 \mathrm{~nm}$, whereas the SP2 ${ }_{\text {Tot }}$ was an eight-channel instrument with a detection range of 70 to $558 \mathrm{~nm}$.

It is well known that the detection efficiency of an SP2 decreases when the diameter of $\mathrm{rBC}$ cores becomes small (i.e., < 70-90 nm; Laborde et al., 2012; Schwarz et al., 2010). Since the main conclusions about black carbon in this manuscript are based on relative measurements taken with two SP2s (i.e., the residual SP2 and the total SP2) the detection sensitivities of the two instruments as a function of size need to be similar. To ensure that this was the case, we carried out the following test: we measured the $\mathrm{rBC}$ size distributions with both SP2s from side-by-side ambient sampling of room air during the post-campaign calibration. Since the two instruments gave slightly different results, we applied a size-dependent correction factor to the SP2 connected to the total inlet to bring the two results in agreement. Shown in Fig. S1 are rBC size distributions measured during cloudfree sampling conditions before the corrections were applied, the size-dependent correction factor applied to the total SP2, and the $\mathrm{rBC}$ size distributions measured during cloud-free sampling after the correction factors were applied. After applying the correction factors to the total SP2, the two SP2s agreed to within $6 \%$ for the total number concentration of rBC particles having diameters between 70 and $220 \mathrm{~nm}$.

\subsection{Refractory black carbon coating thickness measurements}

In addition to measuring the incandescence signal, the SP2 measures the elastically scattered light from $\mathrm{rBC}$ and nonrBC-containing particles with two avalanche photodiodes (APDs). Both APDs were set to the high gain setting for collection, and one of the APDs was a split detector. The APDs generate a time dependent signal as particles pass through the Gaussian laser beam. The split detector APD can be used to obtain position information, whereas the APD without the split detector is used to obtain information on the elastic scattering intensity from particles (Gao et al., 2007). The information from the two APDs combined can be used to determine the coating thickness on $\mathrm{rBC}$ cores as described by Gao et al. (2007). However, in the study presented here, a large fraction of $\mathrm{rBC}$ particles evaporated before the notch position in the split detector, due to poor alignment of the split detector. As a result, position information could not be obtained reliably for a large fraction of the $\mathrm{rBC}$ particles. A similar observation has previously been reported (Taylor et al., 2014). Since position information could not be determined reliably for a large fraction of $\mathrm{rBC}$ particles, coating thicknesses were not determined using the approach described by Gao et al. (2007). Instead, we used the maximum intensity in the elastic scattering signal from the non-split APD detector to determine lower limits to the coating thickness on the rBC particles. A similar approach has been previously used (Subramanian et al., 2010). This coating analysis was only performed on the data from the residual SP2. In other words, we only extracted coating information for rBCcontaining particles sampled from the residual inlet. When rBC-containing particles intersect with the laser beam the particles are heated, and any coating material will evaporate. As a result, the maximum elastic scattering signal measured with the non-split APD detector may not represent the original size of the coated $\mathrm{rBC}$ particle. Because of the evaporation process, the maximum intensity from the non-split APD detector only provides a lower limit to the coating thicknesses of rBC-containing particles (Gao et al., 2007; Subramanian et al., 2010).

The signal from the non-split detector was calibrated using polystyrene latex (PSL) beads (200 and $300 \mathrm{~nm}$ in diameter). This gives a calibration curve that relates the amplitude of the measured scattering signal to the scattering intensity determined from Mie calculations. These Mie calculations involved calculating the scattering intensity for each PSL size over the solid angle of the SP2 detector (a full-angle cone of $65^{\circ}$ at $45^{\circ}$ and $135^{\circ}$ from the laser axis (Gao et al., 2007; Schwarz et al., 2008b) using a Mie code (Leinonen) based on that of Mätzler (2002a, b). The refractive index used for the PSL Mie calculations was 1.59-0.0i.

Since the mass of the $\mathrm{rBC}$ core is known from the incandescence signal and the scattering amplitude is known from the non-split APD detector, a core-shell Mie model can be employed to determine what coating thickness would give the measured scattering signal for that particular particle (Gao et al., 2007; Schwarz et al., 2008b). In this work a core-shell Mie model was used to construct a lookup table for core diameters of 60 to $220 \mathrm{~nm}$ (in $1 \mathrm{~nm}$ increments) and shell thicknesses from 0 to $360 \mathrm{~nm}$ (in $1 \mathrm{~nm}$ increments). The complex index of refraction used for the core was 2.261.26i (Moteki et al., 2010; Taylor et al., 2014) and for the shell, $1.5-0.0 i$, which is consistent with that of dry sulfate or sodium chloride (Metcalf et al., 2012; Schwarz et al., 2008a, b). The PSL calibration was used to scale all calculated values to measured values. The elastic scattering amplitudes and the $\mathrm{rBC}$ core diameters were then used with this lookup table to determine the lower limits to the coating thicknesses for each $\mathrm{rBC}$-containing particle. It should be noted that the coating thicknesses have not been validated experimentally, but merely provide consistency between the observed optical scattering and Mie theory.

For small particles, although the incandescence measurements can size $\mathrm{rBC}$ cores down to $\sim 70 \mathrm{~nm}$, the SP2 elas- 
tic scattering optical detection limit means that scattering from bare $\mathrm{rBC}$ cores below $\sim 110 \mathrm{~nm}$ cannot be measured. As particle size decreases below $110 \mathrm{~nm}$, thicker and thicker coatings are required to produce a measurable scattering signal. In this analysis any particle with no measurable scattering signal was assumed to have a coating thickness of 0 (i.e., they were assumed to be bare $\mathrm{rBC}$ cores), even though they may actually have had a thin coating. This also leads to a lower limit for coating thicknesses for particle sizes below $\sim 110 \mathrm{~nm}$. The fraction of particles with no detectable scattering was $33 \%$ for Cloud 2 and $17 \%$ for Cloud 3 .

For large rBC cores, the optical detector became saturated when even relatively modest coatings were present. For example, the scattering from a $220 \mathrm{~nm} \mathrm{rBC}$ core with a coating thickness of $40 \mathrm{~nm}$ would saturate the SP2 optical detector. In this analysis, the coatings for particles with saturated scattering signals were calculated using the saturation limit of the detector, again resulting in a lower limit for coating thickness. The fraction of particles with saturated scattering signals was $6 \%$ for Cloud 2 and $4 \%$ for Cloud 3 .

In summary, due to the optical detection limits of the nonsplit detector and due to evaporation of the coatings in the laser beam, the coating thicknesses determined in this work, are lower limits to the true coating thicknesses.

\subsection{Size distribution measurements of the bulk aerosol}

Two instruments were used to measure size distributions of the bulk aerosol (see Fig. 1). Size distributions of the bulk aerosol sampled from the total inlet were determined with a scanning electrical mobility spectrometer (SEMS, model 2002, BMI, Hayward, CA) coupled to a condensation particle counter (CPC, model 3781, TSI, St. Paul, MN), which counted particles into 61 discrete size bins from 0.01 to $1 \mu \mathrm{m}$ with a $5 \mathrm{~min}$ scan time interval. Size distributions of bulk aerosol, sampled from the residual inlet, were determined with a scanning mobility particle sizer (SMPS, model 3034, TSI, St. Paul, MN), which recorded particle counts into 55 size bins from 10 to $487 \mathrm{~nm}$ with a 3 min scan time interval. Both the SEMS and SMPS operate based on the coupling of a size-selecting differential mobility analyzer and a condensational growth particle counter. During cloud-free sampling periods, the total number concentration of particles between 70 and $400 \mathrm{~nm}$ measured with the SMPS and SEMS agreed to within $4 \%$.

\subsection{Aerosol mass spectrometry}

To characterize the chemical composition of the cloud droplet residuals an online aerosol mass spectrometer (HRToF-AMS, Aerodyne Research Inc., Billerica, MA) was operated downstream of the CVI on the residual inlet. The HRToF-AMS measures non-refractory, sub-micrometer aerosol chemical composition at high time resolution (DeCarlo et al., 2006). Here we only consider data measured by the
HR-ToF-AMS in its mass-spectrum and V modes of operation. These data were recorded as 2 min averages every 4 6 min, depending on how many other modes of operation (W-mode, light scattering) the instrument was alternating between. Size-resolved composition data for the residual particles measured by the HR-ToF-AMS in time-of-flight mode are not considered here since the signal was generally at or below the detection limit. Standard quantification procedures (Allan et al., 2004) were applied to the mass spectra measured by the HR-ToF-AMS to determine the relative concentrations of the non-refractory species (organic, nitrate, sulfate, ammonium and chloride) typically reported by aerosol mass spectrometry.

\subsection{Back trajectories}

Air mass back trajectories were calculated using the NOAA Hybrid Single Particle Lagrangian Integrated Trajectory Model (HYSPLIT; Draxler and Rolph, 2013; Rolph, 2013). All trajectory calculations used the National Centers for Environmental Predictions EDAS meteorological data set. Trajectories were calculated starting at $10 \mathrm{~m}$ a.g.1., $96 \mathrm{~h}$ backwards in time, and at hourly intervals throughout the entire period of cloud sampling.

\subsection{Cloud properties}

A fog monitor (FM-100, model 100, DMT, Boulder, CO), which is a forward scattering optical spectrometer, was located approximately $50 \mathrm{~cm}$ above the top of the container, $1 \mathrm{~m}$ from the residual inlet, and $1.5 \mathrm{~m}$ from the total inlet. The instrument was mounted on a freely rotating board allowing it to be turned into the wind when the wind direction was obvious. Details of the operational theory of the FM-100 can be found in Eugster et al. (2006) and Spiegel et al. (2012). Briefly, ambient droplet-laden air is pumped through a wind tunnel and carried to a sizing region where droplets pass through a laser beam (wavelength $=658 \mathrm{~nm}$ ). Light that is scattered in the forward direction from a droplet crossing the laser beam is collected by photodetectors and the signals measured are used to assign the droplet to a size bin. From the measured cloud droplet size distribution both the total cloud droplet number concentration (CDNC) and the amount of liquid water content (LWC) present can be determined (Spiegel et al., 2012). The FM-100 used in this study collected droplet counts from droplets with diameters from 2 to $50 \mu \mathrm{m}$ using the manufacture's predefined 20 size bins. The size bin widths using this configuration were $2 \mu \mathrm{m}$ for droplets $<20 \mu \mathrm{m}$ and $3 \mu \mathrm{m}$ for droplets $>20 \mu \mathrm{m}$. Calibrations of the FM-100 were performed by Droplet Measurement Technologies prior to installation. 

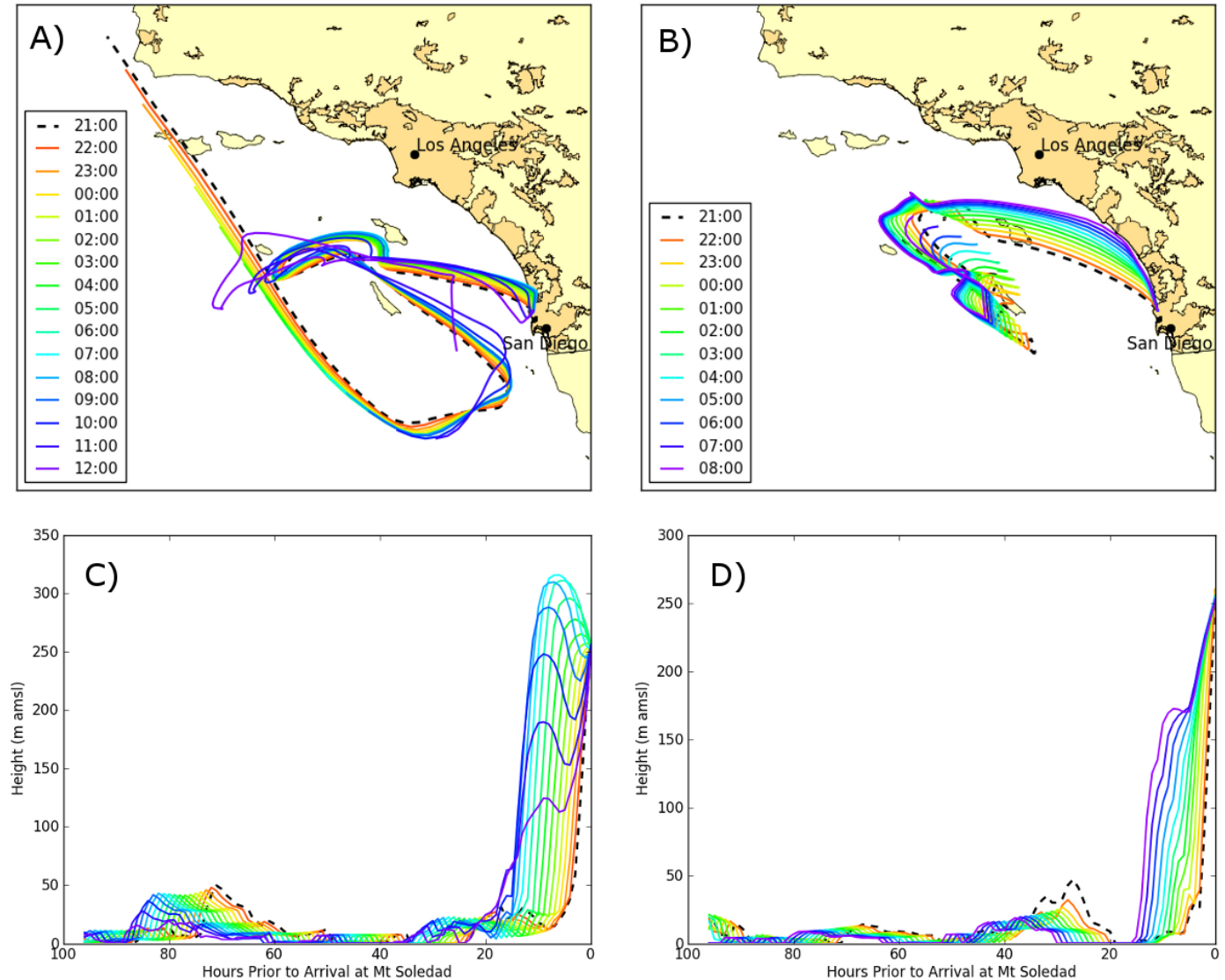

Figure 2. In-cloud HYSPLIT 96 h back trajectories ending at hourly intervals for Cloud 2 (12 June 21:00 to 13 June 12:00 PDT) in (a) and (c), and Cloud 3 (17 June 21:00 to 18 June 08:00 PDT) in (b) and (d). All back trajectories started at 10 ma.g.1. Darker yellow regions on land in panels (a) and (b) indicate densely developed urban areas containing 50000 or more people (United States Census Bureau). Panels (c) and (d) show the vertical profiles over the same hourly intervals shown in (a) and (b).

\section{Results and discussion}

\subsection{Back trajectories}

The back trajectories for Cloud 2 (Fig. 2a, c) show that the air mass spent most of the previous $96 \mathrm{~h}$ over the Pacific Ocean and arrived at the sampling site from a northwesterly direction. During the first part of Cloud 2 (from 12 June 21:00 to 13 June 08:00 PDT), the back trajectories became progressively more northerly and the air mass began traveling towards large populated urban regions. Towards the end of the cloud event (at $\approx 09: 00$ PDT on 13 June) the winds shifted to southwesterly. Based on the back trajectories, the air mass for Cloud 2 traveled $\approx 40-50 \mathrm{~km}$ over land before reaching the sampling site. In addition, the air mass spent a significant amount of time close to the ocean surface prior to being lifted up to the sampling site (Fig. 2c).

The back trajectories for Cloud 3 (Fig. 2b, d) also show that the air mass spent the majority of the previous $96 \mathrm{~h}$ over the Pacific Ocean before arriving at the site. At the start of Cloud 3 (17 June, 21:00 to 22:00 PDT) the air mass arrived from the northwest. Throughout the remainder of the cloud event (17 June 23:00 to 18 June 08:00 PDT) the air mass continued to shift farther north, and by the end of the cloud event (18 June 08:00 PDT) the air mass was traveling south along the coastline before arriving at the sampling site. The back trajectories indicate that the air mass traveled $\approx 10-20 \mathrm{~km}$ over land prior to arriving at the sampling site. Similar to Cloud 2, the air spent a significant amount of time close to the ocean surface prior to being lifted up to the sampling location (Fig. 2d). Since the trajectories during both cloud events are close to the coastline for a period of time, it is likely these air masses contained both marine particles and anthropogenic emissions.

\subsection{Meteorological conditions and cloud properties}

For the purposes of this study, the data were classified as in-cloud and included for analysis if they met the following criteria: (1) the $5 \mathrm{~min}$ averaged CVI counterflow was within $\pm 6 \%$ of the mean counterflow (i.e., $\pm 5 \sigma$, where $\sigma$ is standard deviation) to ensure only periods of stable CVI 


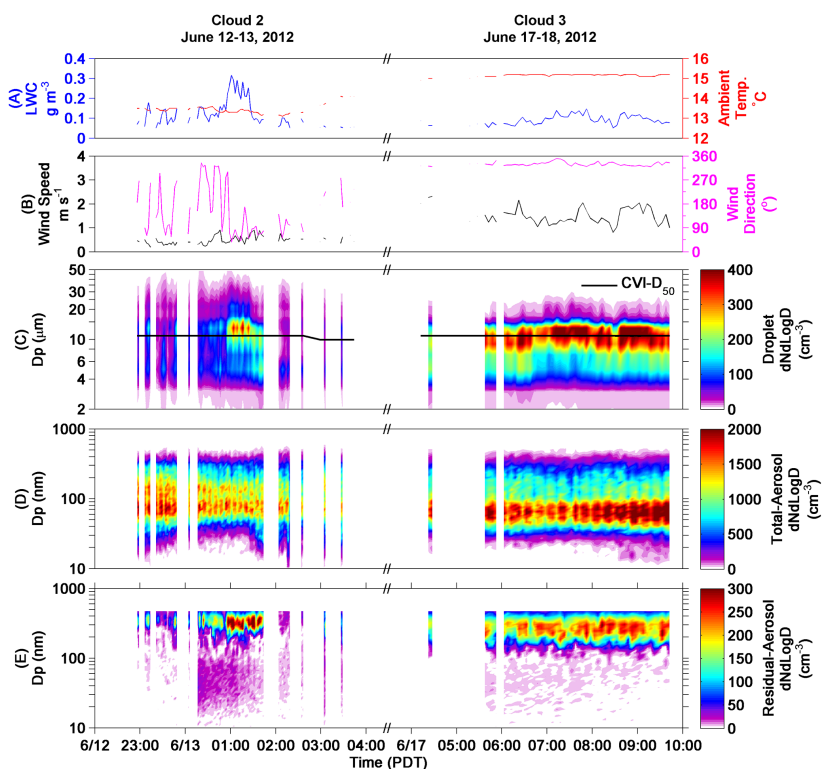

Figure 3. Time series data for both Cloud 2 (left side) and Cloud 3 (right side) showing liquid water content (LWC, blue trace) and ambient temperature (red trace) in (a); wind speed and direction in (b); cloud droplet number size distributions with the CVI- $D_{50}$ (black trace) overlaid in (c); the number size distribution for the total aerosol in (d), and the residual aerosol in (e). All data shown are 5 min averages and meet the criteria discussed in the text.

flows were included; and (2) the 5 min averaged LWC was greater than $0.05 \mathrm{~g} \mathrm{~m}^{-3}$ to remove periods of entrainment, or "patchy" regions of the cloud as much as possible (Cozic et al., 2007).

The measured cloud properties as a function of time are shown in Fig. 3a-c, where Cloud 2 is shown on the left side and Cloud 3 is shown on the right side of the plot. Cloud 2 was characterized by a median temperature of $13.4^{\circ} \mathrm{C}$, a median wind velocity of $0.5 \mathrm{~m} \mathrm{~s}^{-1}$ (10th and 90th percentiles of 0.3 and $0.8 \mathrm{~m} \mathrm{~s}^{-1}$ ) a median wind direction of $126^{\circ}$ (10th and 90th percentiles of 60 and $297^{\circ}$ ), and a median LWC of $0.10 \mathrm{~g} \mathrm{~m}^{-3}$. During the middle portion of Cloud 2 (13 June, 01:00 to 02:00 PDT), the droplet distributions clearly show an interval where the number of droplets above the CVI- $D_{50}$ (black trace overlaid on panel c) increases significantly, which coincides, in time, with a sharp increase in LWC. Cloud 3 was characterized by a median temperature of $15.2^{\circ} \mathrm{C}$, a median wind velocity of $1.4 \mathrm{~m} \mathrm{~s}^{-1}$ (10th and 90th percentiles of 1.1 and $2.0 \mathrm{~m} \mathrm{~s}^{-1}$ ), a median wind direction of $328^{\circ}$ (10th and 90th percentiles of 322 and $341^{\circ}$ ), and a median LWC of $0.09 \mathrm{~g} \mathrm{~m}^{-3}$.

The cloud droplet number and volume size distributions, averaged over the entire event, are shown in Fig. 4, and further summarized in Table 1. Cloud 3 had a CDNC of $146 \mathrm{~cm}^{-3}$, a factor of 2 higher than during Cloud 2 $\left(68 \mathrm{~cm}^{-3}\right)$.

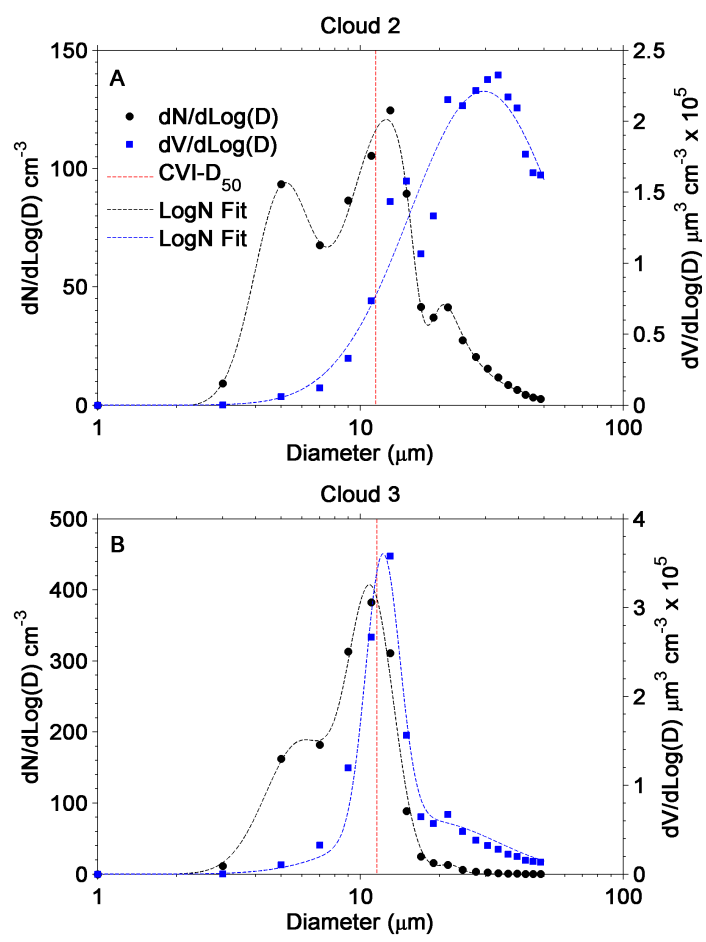

Figure 4. Average cloud droplet number size distributions for Cloud 2 (a) and Cloud 3 (b) measured by the FM-100 (black circles) and fit with a lognormal distribution function (black dashed lines). The average cloud droplet volume distributions (blue squares) and lognormal fits (blue dashed lines) are also shown for each cloud event. The CVI- $D_{50}$ is indicated on each panel by a red dashed line.

From the calculated CVI- $D_{50}$ and the fits to the droplet size distribution (Fig. 4), the number and volume fraction of droplets sampled by the CVI were determined. The results are summarized in Table 1. During Cloud 2, the number fraction of droplets larger than the CVI- $D_{50}$ was about $38 \%$ and for Cloud 3 the fraction sampled was about $24 \%$. Since only the larger droplets were sampled by the CVI during these two cloud events, the results presented herein are only representative of the larger droplet population.

\subsection{Size distributions}

Average size distributions of the bulk aerosol particles and rBC particles measured from the total and residual inlets for both Cloud 2 and Cloud 3 are shown in Fig. 5. Data are plotted in two ways: on a $\log$ scale, in panels $a$ and $b$ and normalized to the respective maximum, in panels $\mathrm{c}$ and $\mathrm{d}$. Table 2 summarizes the results obtained from the size distribution analysis. All size distributions shown in Fig. 5 have been corrected for differences in instrument sensitivity, and all residual distributions have been corrected for the CVI enhancement factor (Sect. S1) and droplet transmission through the CVI (Sect. S4). 
Table 1. Summary of cloud microphysical properties showing the average CVI cut-size $\left(\mathrm{CVI}-\mathrm{D}_{50}\right)$ where the uncertainty stems from the calculated cut-size (see text for details); average liquid water content (LWC) and 1 standard deviation; and the cloud droplet number $\left(\mathrm{CDNC}_{\mathrm{Tot}}\right)$ and volume $\left(\mathrm{Vol}_{\mathrm{Tot}}\right)$ concentration for droplets with diameters between 2 and $50 \mu \mathrm{m}$. Also shown are the number $\left(\frac{\mathrm{CDNC}_{\mathrm{Samp}}}{\mathrm{CDNC}_{\mathrm{Tot}}}\right)$ and volume $\left(\frac{V_{\text {olsamp }}}{V_{\text {ol }} \text { Tot }}\right)$ fractions of droplets sampled, where $\mathrm{CDNC}_{\text {Samp }}$ and Volsamp are the number and volume concentrations, respectively, for the fraction of droplets sampled.

\begin{tabular}{|c|c|c|c|c|c|c|c|}
\hline Cloud no. & Date Sampled & CVI- $D_{50}(\mu \mathrm{m})$ & $\operatorname{LWC}\left(\mathrm{g} \mathrm{m}^{-3}\right)$ & $\mathrm{CDNC}_{\mathrm{Tot}}\left(\mathrm{cm}^{-3}\right)$ & $\frac{\mathrm{CDNC}_{\text {Samp }}}{\mathrm{CDNC}_{\text {Tot }}}$ & $\begin{array}{l}\mathrm{Vol}_{\mathrm{Tot}} \\
\left(\mu \mathrm{m}^{3} \mathrm{~m}^{-3}\right)\end{array}$ & $\frac{\text { Vol }_{\text {Samp }}}{\text { Vol Tot }_{\text {Tot }}}$ \\
\hline 2 & $\begin{array}{l}\text { 12-13 June } 2012 \\
20: 43-11: 35 \text { PDT }\end{array}$ & $11.5 \pm 0.72$ & $0.13 \pm 0.07$ & 67.67 & $0.38 \pm 0.03$ & $1.24 \times 10^{5}$ & $0.91 \pm 0.02$ \\
\hline 3 & $\begin{array}{l}\text { 17-18 June } 2012 \\
20: 36-07: 52 \text { PDT }\end{array}$ & $11.6 \pm 0.72$ & $0.09 \pm 0.02$ & 145.8 & $0.24 \pm 0.1$ & $8.88 \times 10^{4}$ & $0.68 \pm 0.10$ \\
\hline
\end{tabular}

Table 2. Averaged number $(N)$ and mass $(M)$ concentrations and modal parameters $D_{\mathrm{g}}$ and $\sigma_{\mathrm{g}}$ for aerosol and $\mathrm{rBC}$ particles during the two cloud events measured at Mt. Soledad. The subscripts Tot and Res represent measurements made from the total and residual inlets, respectively.

\begin{tabular}{lrrrr}
\hline & \multicolumn{2}{c}{ Cloud 2 } & \multicolumn{2}{c}{ Cloud 3 } \\
\cline { 2 - 5 } & Aerosol & rBC & Aerosol & rBC \\
\hline$N_{\text {Tot }}\left(\mathrm{cm}^{-3}\right)$ & 980.8 & 75.24 & 994.0 & 62.13 \\
$M_{\text {Tot }}\left(\mathrm{ng} \mathrm{m}^{-3}\right)$ & - & 73.41 & - & 61.83 \\
$D_{\mathrm{g}, \text { Tot }}(\mathrm{nm})$ & 107.7 & $<0.07$ & 80.54 & $<0.07$ \\
$\sigma_{\mathrm{g}, \text { Tot }}$ & 1.577 & - & 1.703 & - \\
\hline$N_{\text {Res }}\left(\mathrm{cm}^{-3}\right)$ & 43.46 & 2.000 & 83.15 & 3.86 \\
$M_{\text {Res }}\left(\mathrm{ng} \mathrm{m}^{-3}\right)$ & - & 2.741 & - & 4.735 \\
$D_{\mathrm{g}, \operatorname{Res}}(\mathrm{nm})$ & 331.9 & 87.30 & 269.2 & 80.72 \\
$\sigma_{\mathrm{g}, \operatorname{Res}}$ & 1.187 & 1.259 & 1.281 & 1.268 \\
\hline
\end{tabular}

\subsubsection{Size distributions measured from the total inlet (BulkAero Tot and rBC $_{\text {Tot }}$ )}

The average size distributions of the bulk aerosol measured with the total inlet (referred to as BulkAeroTot for the remainder of the document) and the average size distributions of the refractory black carbon measured with the total inlet (referred to as $\mathrm{rBC}_{\mathrm{Tot}}$ for the remainder of the document) are shown in Fig. 5. A single mode lognormal distribution function was fit to the BulkAeroTot data, yielding mean geometric diameters $\left(D_{\mathrm{g}}\right)$ of 108 and $81 \mathrm{~nm}$ with geometric standard deviations $\left(\sigma_{\mathrm{g}}\right)$ of 1.58 and 1.70 for Clouds 2 and 3 , respectively. Integration of the number distribution during Cloud 2 results in a total number concentration $\left(N_{\mathrm{Tot}}\right)$ for the bulk aerosol of $981 \mathrm{~cm}^{-3}$. Likewise, $N_{\text {Tot }}$ during Cloud 3 was measured to be $994 \mathrm{~cm}^{-3}$. Previous measurements in the marine boundary layer have classified the environment as "clean" marine if the number of particles is $\leq 300-500 \mathrm{~cm}^{-3}$ and "polluted" marine if the number concentrations are $\geq 400-1500 \mathrm{~cm}^{-3}$ (Andreae, 2009; Bates et al., 2000; Glantz and Noone, 2000; Hawkins et al., 2010; O'Dowd et al., 2001; Pirjola and O'Dowd, 2000; Twohy et al., 2005). Thus, the particle concentrations measured at Mt. Soledad, in addition to the back trajectories, suggest that for both clouds the air masses can be classified as polluted marine aerosols. The size distributions of BulkAeroTot as a function of time are also included in Fig. 3d for comparison.

The $\mathrm{rBC}_{\mathrm{Tot}}$ size distributions for each cloud are shown in Fig. 5. The $D_{\mathrm{g}}$ for $\mathrm{rBC}_{\text {Tot }}$ (assuming the number distributions are lognormal) during both events lies somewhere in the nucleation mode at $<70 \mathrm{~nm}$, which is outside the detection range for the SP2. Integration of the $\mathrm{rBC}_{\text {Tot }}$ distributions, from 70 to $220 \mathrm{~nm}$, yields an $N_{\text {Tot }}$ of $75 \mathrm{~cm}^{-3}$ during Cloud 2 and $62 \mathrm{~cm}^{-3}$ in Cloud 3 . Assuming a black carbon density of $1.8 \mathrm{~cm}^{-3}$ the total mass concentrations of $\mathrm{rBC}\left(M_{\mathrm{Tot}}\right)$ are 73 and $62 \mathrm{ng} \mathrm{m}^{-3}$ for Clouds 2 and 3, respectively (Table 2). The $\mathrm{rBC}_{\mathrm{Tot}}$ mass concentrations observed at Mt. Soledad were higher than concentrations measured in clean marine air (Cooke et al., 1997; Shank et al., 2012), but considerably lower than concentrations measured in most urban environments (see Table 1 in Metcalf et al., 2012).

\subsubsection{Size distributions measured from the residual inlet (BulkAero Res $_{\text {and }} \mathbf{r B C}_{\text {Res }}$ )}

Average size distributions of the bulk aerosol measured from the residual inlet (referred to as BulkAero ${ }_{\text {Res }}$ for the remainder of the document) are also shown in Fig. 5. The size distributions of the BulkAero Res indicate that it was mostly the larger particles of the BulkAero Tot distributions that were incorporated into the sampled cloud droplets. The size distributions of BulkAerones as a function of time for both cloud events are included in Fig. 3e for comparison.

The size distributions for BulkAero Res shown in Fig. 5 have a local minimum at $110 \mathrm{~nm}$ for Cloud 2 and $90 \mathrm{~nm}$ for Cloud 3. The particles observed at sizes less than the local minima may be due to droplet shattering, a leak in the CVI (Pekour and Cziczo, 2011; Schwarzenboeck, 2000; Vidaurre et al., 2011), or possibly entrainment or precipitation processes in the clouds (Targino et al., 2007). 


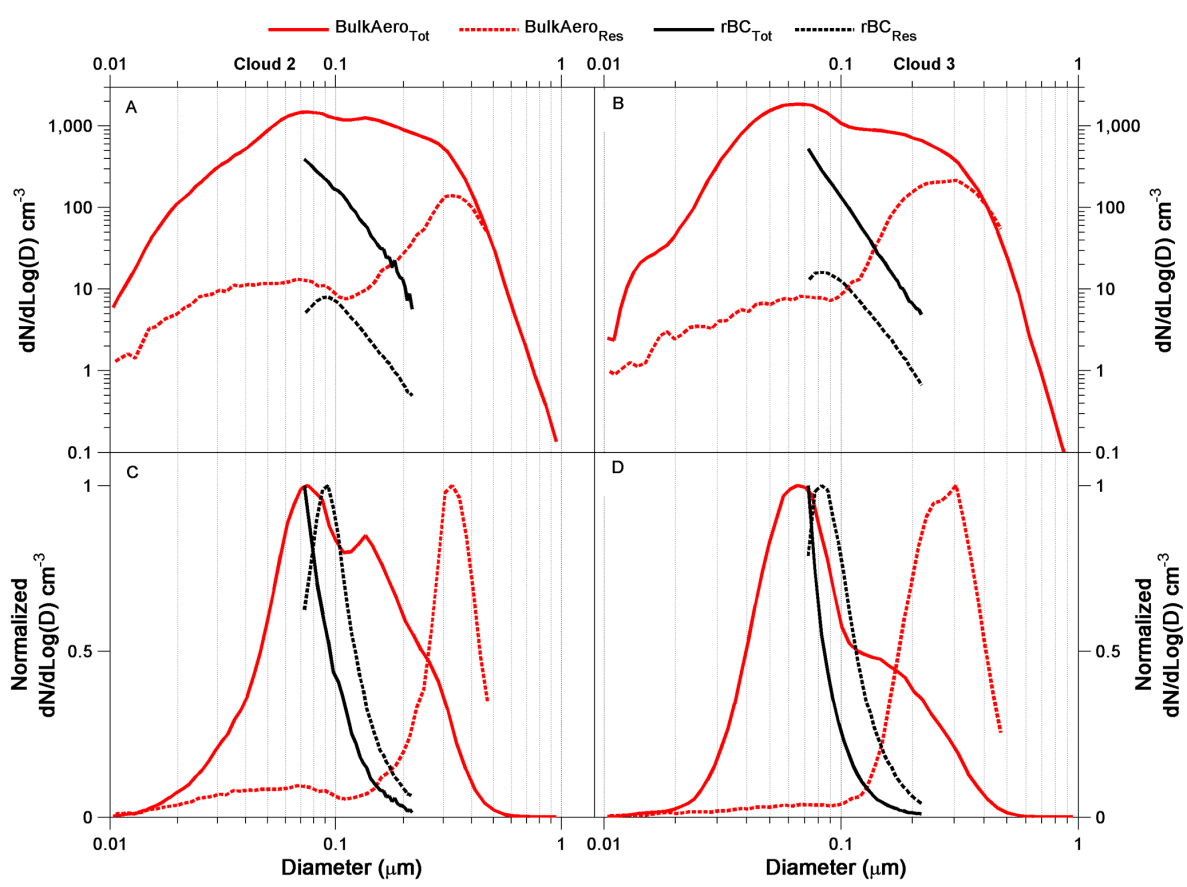

Figure 5. Summary of the averaged number size distributions for Cloud 2 (a, c) and Cloud 3 (b, d) for the total aerosol (red solid lines); residual aerosol (red dashed lines); total $\mathrm{rBC}$ as a function of core diameter (black solid lines); residual $\mathrm{rBC}$ as a function of core diameter (black dashed lines). Both the aerosol and rBC for each cloud event are shown in two ways: a log scale (a, b) to highlight the relative differences between the aerosol and $\mathrm{rBC}$ as well as normalized to the respective maximum value (c, d) to highlight the shift in size distributions. All residual distributions have been corrected for instrument sensitivity (Fig. S1), CVI enhancement (Sect. S1), and droplet losses (Sect. S4).

Figure 5 also shows the size distributions of the $\mathrm{rBC}$ residuals measured with the CVI. Figure 5 shows that $\mathrm{rBC}$ cores smaller than $100 \mathrm{~nm}$ are incorporated into cloud droplets. In addition, they are overall larger than the $\mathrm{rBC}_{\mathrm{Tot}}$. Fitting the $\mathrm{rBC}_{\mathrm{Res}}$ size distributions (assuming these distributions are lognormal) results in mean geometric diameters of 87 and $81 \mathrm{~nm}$ for Clouds 2 and 3, respectively.

\subsection{Size-resolved activated fraction}

The size-resolved activated fraction $\left[\mathrm{AF}\left(D_{\mathrm{p}}\right)\right]$ for $\mathrm{rBC}$ and the bulk aerosol were calculated by taking the ratio of the number distributions measured with the residual inlet to the number distributions measured with the total inlet. Prior to calculating $\operatorname{AF}\left(D_{\mathrm{p}}\right)$, a spline interpolation algorithm was applied to the $\mathrm{rBC}$ and bulk aerosol size distributions. After a spline interpolation was applied to the data, the following equation was used to calculate the size-resolved activated fraction:

$\operatorname{AF}\left(D_{\mathrm{p}}\right)=\frac{N_{\text {Res }}\left(D_{\mathrm{p}}\right) \times \mathrm{CF}\left(D_{\mathrm{p}}\right)}{N_{\mathrm{Tot}}\left(D_{\mathrm{p}}\right) \times \mathrm{EF} \times \mathrm{DT}}$,

where $N_{\text {Res }}\left(D_{\mathrm{p}}\right)$ is the number of residual particles as a function of size, $\operatorname{CF}\left(D_{\mathrm{p}}\right)$ is the size-resolved instrument sensitivity correction factor, $N_{\text {Tot }}\left(D_{\mathrm{p}}\right)$ is the number of particles measured with the total inlet as a function of size, EF is the CVI enhancement factor (Sect. S1), and DT is the droplet transmission factor through the CVI. Calculations of the droplet transmission factor are discussed in the Supplement Sect. S4 and plotted in Fig. S3. $\mathrm{CF}\left(D_{\mathrm{p}}\right)$, which correct for variances in instrument detection efficiencies, were determined from a $12 \mathrm{~h}$ period of cloud-free air on 5 June 2012 for the bulk aerosol and from side-by-side ambient sampling of room air during the post-campaign for $\mathrm{rBC}$. Additional information on the measurement of $\mathrm{CF}\left(D_{\mathrm{p}}\right)$ for $\mathrm{rBC}$ is given in the Supplement (Sect. S2)

The median $\operatorname{AF}\left(D_{\mathrm{p}}\right)$ for the bulk aerosol and $\mathrm{rBC}$ are presented in Fig. 6, where the error bars represent the 10th and 90th percentiles for each $10 \mathrm{~nm}$ bin. Un-coated $\mathrm{rBC}$ particles with sizes $<100 \mathrm{~nm}$ are not expected to be incorporated into cloud droplets by nucleation for typical supersaturations reached in stratocumulus clouds. Figure $6 \mathrm{a}$ and $\mathrm{b}$ show that the $\mathrm{AF}$ of $\mathrm{rBC}$ cores is significant, even for core diameters $\leq 100 \mathrm{~nm}$. These results can be explained by the presence of large coatings surrounding the core (see Sect. 3.6 below). Since the rBC size distributions were normalized to differences in instrument sensitivity, the decreased $\mathrm{rBC}$ AF at smaller diameters is not a result of the different detection efficiencies of the SP2 instruments. Figure $6 a$ and $b$ also show that during both clouds the $\mathrm{AF}$ for $\mathrm{rBC}$ cores is larger than the $\mathrm{AF}$ for the bulk aerosol at diameters $<\approx 150 \mathrm{~nm}$. Again, this can be explained by the presence of thick coatings on the rBC cores. Since the fraction of cloud droplets sampled by 


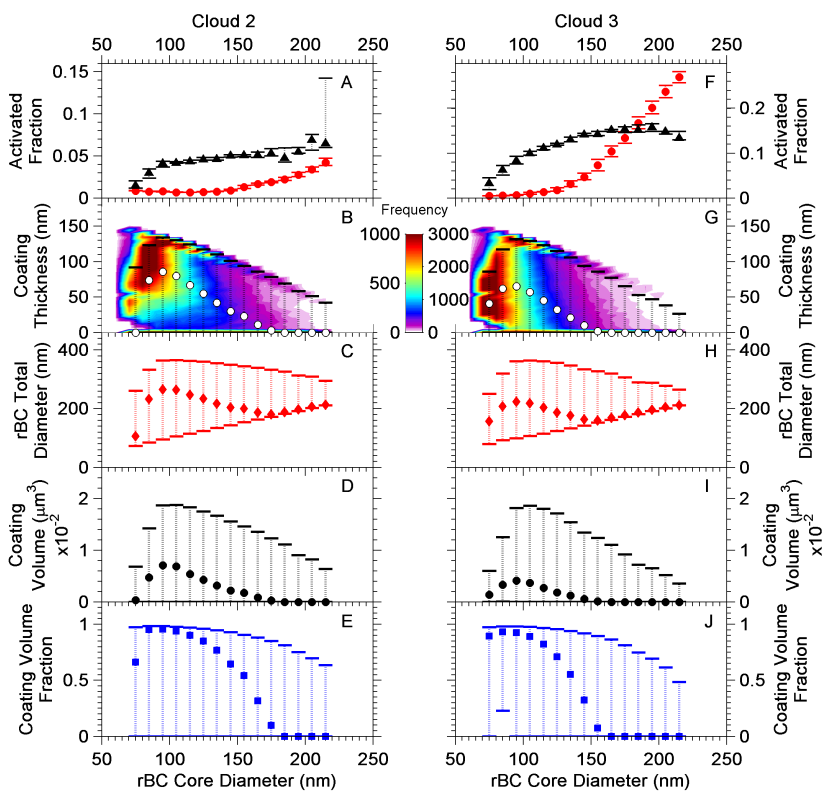

Figure 6. Shown in (a) and (f) are the median size-dependent activated fraction (AF) for the aerosol (red circles), and rBC (black triangles) for Clouds 2 and 3, respectively, where the error bars represent the 10th and 90th percentiles. The bottom axes represent particle diameter for the aerosol and core diameter for rBC. Panels (b) and (g) show a 2-D histogram of coating thickness with the median values (white circles) overlaid on top, where the error bars show the 10th and 90th percentiles. Panels (c) and (h) show rBC total diameter (i.e., the core and the coating), (d) and (i) the coating volume, and (e) and (j) the coating volume fraction, all as a function of $\mathrm{rBC}$ core diameter.

the CVI was $<100 \%$, the calculated AF should be considered as lower limits to the total fraction activated during the two cloud events.

\subsection{Mechanism of incorporating $\mathrm{rBC}$ into cloud droplets}

Two possible mechanisms exist for incorporating rBCcontaining particles into cloud droplets: nucleation scavenging and coagulation between the $\mathrm{rBC}$-containing particles and cloud droplets. Based on calculations (Sect. S3), the fraction of rBC-containing particles expected to be incorporated into the cloud droplets by coagulation was on the order of $<1 \%$. This suggests that the dominant mechanism for incorporating $\mathrm{rBC}$ particles into the cloud droplets studied was nucleation scavenging. First, the fraction of rBC-containing particles activated into cloud droplets increases as the size of the $\mathrm{rBC}$ cores increases (Fig. 6a, b). If coagulation dominated, we would expect to see an opposite trend. Second, calculated coagulation rates together with estimated lifetimes of the cloud droplets cannot explain the fraction of $\mathrm{rBC}$ containing particles activated into the cloud droplets - the calculated coagulation rates are too small (Sect. S3).

\subsection{Lower limits to coating thickness of rBC residuals}

Lower limits to the coating thicknesses on the $\mathrm{rBC}$ cores were determined using a core and shell Mie model. The median values from this analysis are shown in Fig. $6 \mathrm{~b}$ and $\mathrm{g}$, where the error bars represent the 10th and 90th percentiles and the symbols represent the medians for each size bin. When calculating lower limits to the coating thicknesses, the particles were idealized as a pure BC core uniformly coated with a non-absorbing material, although the actual particle morphology may be more complicated (Sedlacek et al., 2012). The results shown in Fig. $6 \mathrm{~b}$ and g give a qualitative explanation for why we see activation of $\mathrm{rBC}$ cores with sizes $<100 \mathrm{~nm}$ : these $\mathrm{rBC}$ cores have relatively thick coatings, which can lower the critical supersaturation required for activation. For example, $95 \mathrm{~nm} \mathrm{rBC}$ cores incorporated into the cloud droplets had a median coating thickness of $65 \mathrm{~nm}$.

Figure $6 \mathrm{~b}$ and $\mathrm{g}$ show that as the $\mathrm{rBC}$ core diameter increased from 75 to approximately $100 \mathrm{~nm}$ the lower limit to the coating thickness also increased. This is likely because as the rBC core diameter increased from 75 to $100 \mathrm{~nm}$, the fraction of particles above the optical detection limit increased. Recall that for $\mathrm{rBC}$-containing particles with diameters $<\approx 100 \mathrm{~nm}$, a relatively large fraction of the coated particles are below the optical detection limits and hence are assigned a coating thickness of zero (Sect. 2.5). After the median coating thickness reached a maximum at an $\mathrm{rBC}$ core diameter of approximately $100 \mathrm{~nm}$, the lower limit to the coating thickness decreased with an increase in $\mathrm{rBC}$ core diameter. This may suggest that the larger $\mathrm{rBC}$ cores had thinner coatings than the smaller $\mathrm{rBC}$ cores that were incorporated into the cloud droplets. Part of the decrease in the lower limit to the coating thickness with an increase in $\mathrm{rBC}$ core diameter could be due to saturation of the optical detector. As mentioned in Sect. 2.5, the optical detector became saturated when the $\mathrm{rBC}$ cores were relatively large and contain a modest coating. In Fig. $6 \mathrm{c}$ and h, we plotted the overall diameter of the rBC-containing particles. In other words, we plotted the sum of the $\mathrm{rBC}$ core diameter plus 2 times the coating thickness. If we disregard the point at $75 \mathrm{~nm}$ (which is likely strongly influenced by the fact that a large fraction of the rBC-containing particles with this core size are below the optical detection limit), we conclude that in order for the rBC-containing particles to be incorporated into the cloud droplets, the overall median diameter of $\mathrm{rBC}$-containing particles must be at least $165 \mathrm{~nm}$ in diameter. Figure $6 \mathrm{c}$ and $\mathrm{h}$ suggest that the overall diameter of the rBC-containing particles is important for activation. This finding is consistent with previous work that has shown that particle diameter is important for activation of non-rBC-containing particles (e.g., Wang et al., 2008).

To further investigate the factors that control activation of the $\mathrm{rBC}$-containing particles, we plotted the coating volume (Fig. 6d, i) and coating volume fraction (Fig. 6e, j) as a function of $\mathrm{rBC}$ core diameter. For discussion purposes we focus 
on the coating volume fraction as a function of size and $\mathrm{rBC}$ core diameters $\geq 85 \mathrm{~nm}$. As discussed above, coating volume fraction at $75 \mathrm{~nm}$ rBC core diameter, is likely strongly influenced by the fact that a large fraction of rBC-containing particles, with this core size, are below the optical detection limit. Figure $6 \mathrm{e}$ and $\mathrm{j}$ show that for $\mathrm{rBC}$ core diameters from 85 to $95 \mathrm{~nm}$, the median coating volume fraction is at least 0.9 . This finding also gives a qualitative explanation for why we see relatively large activated fractions of small $\mathrm{rBC}$ cores in the cloud residuals.

As the $\mathrm{rBC}$ core diameter increased above approximately $100 \mathrm{~nm}$, the lower limit to the coating volume fraction decreased. This could be because larger $\mathrm{rBC}$ cores need less coating material in order to be incorporated into cloud droplets. Part of the decrease in coating volume fraction at $\mathrm{rBC}$ core diameters above $100 \mathrm{~nm}$ could also be due to the saturation limit of the optical scattering detectors, as discussed above.

\subsection{In-cloud aqueous-phase chemistry}

In the discussion above, we assumed the coatings on the $\mathrm{rBC}$ cores were present before incorporation into the cloud droplets. However, some of the coating material may have formed after the $\mathrm{rBC}$ cores were incorporated into the cloud by aqueous-phase chemistry. As mentioned in the Supplementary Material (Sect. S3), the upper limits to residence times of air parcels in the clouds sampled at Soledad were likely $\sim 1 \mathrm{~h}$. Whether significant aqueous-phase chemistry can occur on this timescale depends on the level of $\mathrm{SO}_{2}$ and oxidants. When $\mathrm{SO}_{2}$ is absorbed by a cloud droplet, it partitions in different forms as a function of $\mathrm{pH}$ : at lower $\mathrm{pH}$ values, the primary aqueous-phase oxidant of dissolved $\mathrm{SO}_{2}$, or $\mathrm{S}(\mathrm{IV})$ is $\mathrm{H}_{2} \mathrm{O}_{2}$; for higher $\mathrm{pH}$ values, ozone and catalyzed aerobic oxidation are important oxidation pathways. Depending on the $\mathrm{pH}$ and available oxidants, conversion of the dissolved $\mathrm{S}(\mathrm{IV})$ to $\mathrm{S}(\mathrm{VI})$ can be fast or slow. The absorption of large amounts of $\mathrm{HNO}_{3}$ or $\mathrm{N}_{2} \mathrm{O}_{5}$ can reduce the $\mathrm{pH}$ significantly, which will require the presence of $\mathrm{H}_{2} \mathrm{O}_{2}$ in order to significantly convert $\mathrm{S}(\mathrm{IV})$ to $\mathrm{S}(\mathrm{VI})$. Since the clouds at Soledad occurred mostly overnight, the primary oxidant $\left(\mathrm{H}_{2} \mathrm{O}_{2}\right)$ was likely lower (and probably near zero). Also, analysis of the cloud water indicated that nitrate was high, and thus the $\mathrm{pH}$ was probably low. Based on these factors, we suspect that aqueous-phase production of sulfate was not large. However, a quantitative estimate of the sulfate produced is not possible since the measurements of $\mathrm{SO}_{2}$ and $\mathrm{H}_{2} \mathrm{O}_{2}$ were not performed at this site. Based on the discussion above, we assumed that a large fraction of the coatings were present before $\mathrm{rBC}$ particles were incorporated into the cloud droplets. However, the production of coating material from in-cloud aqueous-phase chemistry cannot be ruled out.

\subsection{Comparison of $\mathrm{rBC}_{\mathrm{Res}}$ as a function of size with predictions based on $\kappa$-Köhler theory}

Sections 3.4 and 3.6 provide a qualitative explanation for how small $\mathrm{rBC}$ cores are incorporated into cloud droplets the $\mathrm{rBC}$ cores have thick coatings leading to overall particle diameters greater than approximately $165 \mathrm{~nm}$. In the following we expand on this qualitative explanation by carrying out a quantitative analysis that shows that the presence of small rBC cores in the cloud residuals is consistent with $\kappa$-Köhler theory. This quantitative analysis consists of the following steps: (1) an estimation of the bulk aerosol composition; (2) an estimation of the critical diameter for activation of the cloud droplets sampled; (3) an estimation of the critical supersaturation required to form the droplets sampled; and (4) a prediction of the critical diameter for activation of $\mathrm{rBC}$ cores. Steps 1-3 are required to carry out the predictions in step 4 .

\subsubsection{Bulk aerosol composition}

A HR-ToF-AMS was used to measure the bulk aerosol composition in residual particles downstream of the CVI. Five species (organic, nitrate, sulfate, ammonium, and chloride) were quantitatively differentiated. Then, based on a simplified ion-pairing scheme similar to Gysel et al. (2007; Sect. S5), the mass fractions of ammonium nitrate, ammonium sulfate, ammonium bisulfate, sulfuric acid, and ammonium chloride were calculated. The results of these calculations are shown in Fig. 7. In order to determine the bulk aerosol hygroscopicity (Eq. 3), the mass fractions of these individual components were first converted to volume fractions using an organic density of $1.4 \mathrm{~g} \mathrm{~cm}^{-3}$ (Moore et al., 2012) and densities reported in Lide (2001) for the inorganic salts.

\subsubsection{The critical diameter for activation of the bulk aerosol in the cloud droplets sampled}

The critical diameter for activation ( $\left.D_{\text {crit }}\right)$ of the bulk aerosol is often calculated by integrating the droplet number distribution from the largest to smallest diameters until the number concentration equals the CDNC sampled (see for example Hersey et al., 2013). Using this method, $D_{\text {crit }}$ was found to be 241 and $239 \mathrm{~nm}$ for Cloud 2 and Cloud 3, respectively. Note these $D_{\text {crit }}$ values apply only to the cloud droplets sampled (i.e., cloud droplets greater than $\approx 11 \mu \mathrm{m}$ ). Different $D_{\text {crit }}$ values would be expected if the entire cloud droplet population were sampled.

\subsubsection{Critical supersaturation for the cloud droplets sampled during the two cloud events}

To estimate the critical supersaturation $\left(S_{\mathrm{C}}\right)$ for the formation of the cloud droplets sampled during the two cloud events (i.e., cloud droplets greater than $\approx 11 \mu \mathrm{m}$ ), the single parameter $\kappa$-Köhler model (Petters and Kreidenweis, 2007) 


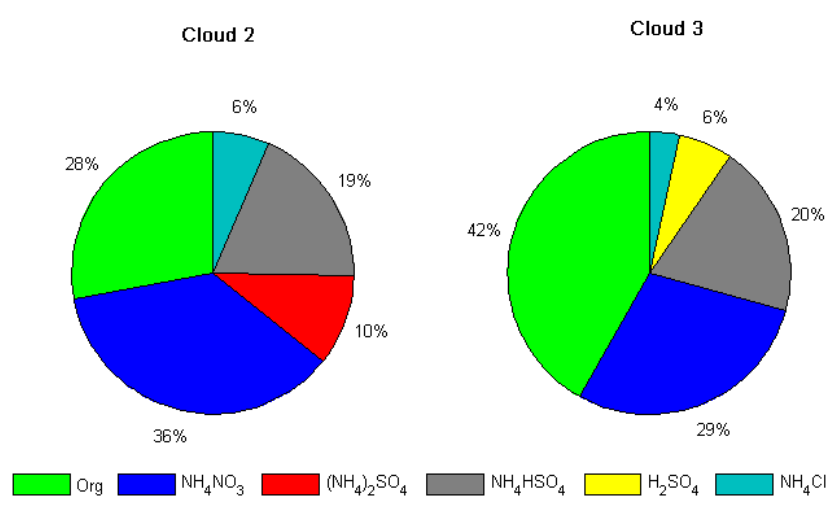

Figure 7. Sub-micrometer non-refractory average aerosol mass fractions for Clouds 2 and 3 based on an ion-pairing scheme (see text and Sect. S5) and measured from a high resolution time-offlight aerosol mass spectrometer.

was used. This model describes the relationship between the water vapor saturation ratio $(S)$ over an aqueous solution droplet, which can be calculated using the following equation:

$S=\frac{D^{3}-D_{\mathrm{p}}^{3}}{D^{3}-D_{\mathrm{p}}^{3}\left(1-\kappa_{\text {Bulk }}\right)} \exp \left(\frac{4 \sigma M_{\mathrm{w}}}{\rho_{\mathrm{w}} \mathrm{RTD}}\right)$

where $D$ is the droplet diameter; $D_{\mathrm{p}}$ is the dry particle diameter; $\sigma$ is the droplet surface tension and is assumed to be that of water, $0.072 \mathrm{~J} \mathrm{~m}^{-2} ; M_{\mathrm{w}}$ is the molecular mass of water; $\rho_{\mathrm{w}}$ is the density of water; $R$ is the universal gas constant; $T$ is the temperature; and $\kappa_{\text {Bulk }}$ is a compositionally specific parameter that describes the bulk aerosol's hygroscopicity. Equation (2) was used to find the $S_{\mathrm{C}}$ needed for a particle of dry diameter $D_{\mathrm{p}}$ to activate (Petters and Kreidenweis, 2007).

The overall hygroscopicity of a particular aerosol follows a simple mixing rule and can be calculated from

$\kappa_{\mathrm{Bulk}}=\sum_{i} \varepsilon_{i} \kappa_{i}$,

where $\varepsilon_{i}$ is the volume fraction and $\kappa_{i}$ is the hygroscopicity parameter for each component $i$ discussed in Sect. 3.8.1. The individual component $\kappa$ values used in Eq. (2) were 0.1 for organic (Lance et al., 2013; Moore et al., 2012; Rose et al., 2010); 0.67 for ammonium nitrate (Petters and Kreidenweis, 2007); 0.61 for ammonium sulfate and ammonium bisulfate (Petters and Kreidenweis, 2007; Wu et al., 2013); and 0.71 for sulfuric acid, which is the average of the range reported in Shantz et al. (2008). The value for ammonium chloride $\kappa$ (1.02) was calculated according to Eq. (A28) in Rose et al. (2008) using a Van 't Hoff factor of 2.

Using the above $\kappa_{i}$ values and the $\varepsilon_{i}$ values discussed in

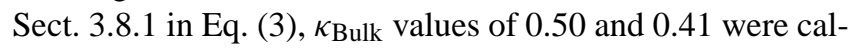
culated for Cloud 2 and Cloud 3, respectively. The $\kappa$ values determined during this study are consistent with the $\kappa$ values suggested by Andreae and Rosenfeld (2008) for marine
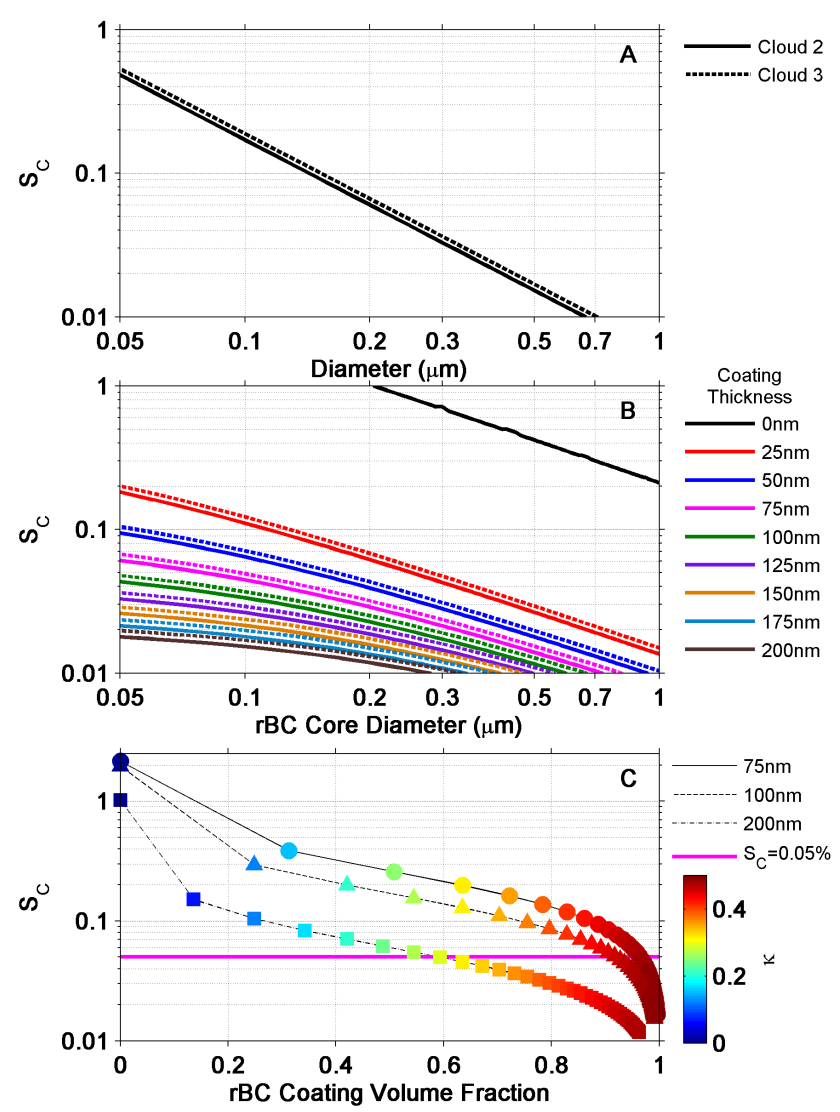

Figure 8. Panel (a) shows the critical supersaturation $\left(S_{\mathrm{C}}\right.$, black lines) as a function of particle dry diameter based on measured AMS bulk compositions and an ion-pairing scheme. Panel (b) shows $S_{\mathrm{C}}$ as a function of $\mathrm{rBC}$ core diameters with coatings ranging from 0 to $200 \mathrm{~nm}$. In (b), the coatings are assumed to have the same composition as the bulk residual aerosol (Fig. 7). The solid lines are for Cloud 2 and the dashed lines are for Cloud 3. Panel (c) shows $S_{\mathrm{C}}$ as a function of $\mathrm{rBC}$ coating volume fraction at three different rBC core diameters $(75,100$, and $200 \mathrm{~nm})$, where each data point is colored by its corresponding $\kappa$. Also shown in panel (c) is the estimated $S_{\mathrm{C}}$ (pink line) determined for both clouds in this study.

aerosols during Cloud 2 and lower than the $\kappa$ values suggested during Cloud 3.

Shown in Fig. 8a are plots of $S_{\mathrm{C}}$ as a function of dry diameter for Cloud 2 (solid line) and Cloud 3 (dashed line) calculated using Eqs. (2) and (3). Combining $D_{\text {crit }}$ (Sect. 3.8.2) with the results plotted in Fig. $8, S_{\mathrm{C}}$ for the cloud droplets sampled can be determined. The points at which $D_{\text {crit }}$ intersect with the calculated $S_{\mathrm{C}}$ traces shown in Fig. 8 result in estimations of $S_{\mathrm{C}}$ values of $0.05 \%$ for both clouds. Note these critical supersaturations apply only to the cloud droplets sampled by the CVI. Different $S_{\mathrm{C}}$ values would be expected if the entire droplet population had been sampled. Theory predicts that the largest droplets in the distribution should have been the first to form, thus formed on particles activated at the lowest supersaturations. During this study, a CCN instrument 
was also connected to the residual inlet and sampled residual particles during the cloud events. Data from this instrument were used to derive an upper limit to the cloud supersaturation applicable to the cloud droplets sampled by the CVI (Modini et al., 2015), and was found to be approximately $0.1 \%$. This upper limit to the cloud supersaturation is approximately consistent with the $S_{\mathrm{C}}$ values reported here using the estimation technique discussed above.

In this determination of $S_{\mathrm{C}}$, several assumptions were made which are addressed separately below: (1) the predominant mechanism for incorporation of particles into droplets was nucleation scavenging, and influences by impaction were negligible (Sect. 3.5); (2) the contribution from sea salt aerosols could be neglected. Based on sea salt mass concentrations measured by the HR-ToF-AMS behind the CVI and calibrated against collocated ion chromatography measurements following a procedure similar to that introduced by Ovadnevaite et al. (2012), we estimated an upper limit of approximately $15 \%$ for the sea salt mass fraction of the cloud residuals (these results will be discussed in detail in a future publication). A sensitivity study (not shown here) indicated a $<8 \%$ decrease in the estimated $S_{\mathrm{C}}$ when a sea salt fraction of $15 \%$ was included; (3) we assumed that the particles were internally mixed and the composition did not depend on size. Since, during this study, the size-dependent AMS data were at or below the detection limit we could not determine if the composition was size dependent. Additionally, no measurements of bulk aerosol mixing state were carried out; and (4) we assumed that the entire fraction of organics was water soluble and represented by a $\kappa$ of 0.1 . To determine if $S_{\mathrm{C}}$ was sensitive to this value, $\kappa$ for organics was varied from 0 to 0.2 , which is roughly consistent with the range of $\kappa$ values reported in the literature for organics (Chang et al., 2010; Lathem et al., 2013; Mei et al., 2013). Over this range of $\kappa$ values, $S_{\mathrm{C}}$ varied by $<4 \%$.

\subsubsection{Predictions of the critical diameter for activation of $\mathrm{rBC}$ cores}

In Fig. $8 \mathrm{~b}$ the critical diameter for activation of $\mathrm{rBC}$ cores for the cloud droplets sampled is calculated using $\kappa$-Köhler theory and assuming coating thicknesses ranging from 0 to $200 \mathrm{~nm}$, which covers the range of coating thicknesses measured. In these calculations the composition of the coating was assumed to be the same as determined by the AMS (Sect. 3.8.1), and the rBC cores were assumed to be insoluble with a $\kappa=0$ (Rose et al., 2010). As expected, in Fig. 8b, $S_{\mathrm{C}}$ decreases as the coating thickness increases at a constant $\mathrm{rBC}$ core diameter. Figure $8 \mathrm{~b}$ also suggests that if the $S_{\mathrm{C}}$ is $\approx 0.05 \%$ and the diameter of the $\mathrm{rBC}$ core is $95 \mathrm{~nm}$, the coating thickness must be between 50 and $75 \mathrm{~nm}$. Our lower limits to the coating thicknesses for an $\mathrm{rBC}$ core diameter of $95 \mathrm{~nm}$ shown in Fig. $6 \mathrm{~b}$ and $\mathrm{g}$ are consistent with these predictions.
In Fig. $8 \mathrm{c}$ we plotted $S_{\mathrm{C}}$ as a function of the $\mathrm{rBC}$ coating volume fraction assuming $\mathrm{rBC}$ core diameters of 75,100 , and $200 \mathrm{~nm}$. This figure illustrates that in order to activate 75 and $100 \mathrm{~nm} \mathrm{rBC}$ cores at a $S_{\mathrm{C}}$ of $0.05 \%$ the $\mathrm{rBC}$ coating volume fraction must be greater than 0.9 . Figure $8 \mathrm{c}$ also shows that for an $\mathrm{rBC}$ core diameter of $200 \mathrm{~nm}$, the coating volume fraction needs to be approximately 0.6 . For $100 \mathrm{~nm} \mathrm{rBC}$ cores the measurements are in good agreement with the predictions (compare Fig. 8c with Fig. 6e, j). For 75 and 200 nm cores the measurements are lower than the predictions. However, the measurements are not inconsistent with the calculations since the measurements represent lower limits.

\section{Summary and conclusions}

Cloud residuals were measured during two cloud events at the top of Mt. Soledad in La Jolla, CA. Back trajectories showed that air masses for both cloud events spent at least $96 \mathrm{~h}$ over the Pacific Ocean and traveled near, or over populated regions before arriving on site. Based on measured bulk aerosol concentrations the two air masses sampled were classified as polluted marine air, a classification consistent with the back trajectories and measured concentrations of black carbon. Size distributions of the bulk aerosol residuals were shifted to larger sizes for both cloud events compared to size distributions measured with the total inlet. The size distributions of $\mathrm{rBC}$ cloud residuals were also shifted towards larger diameters when compared to the size distributions of $\mathrm{rBC}$ measured with the total inlet. The activated fractions of $\mathrm{rBC}$ determined from the measurements ranged from 0.01 to 0.1 for $\mathrm{rBC}$ core diameters ranging from 70 to $220 \mathrm{~nm}$. This type of data will be useful for constraining models used to predict $\mathrm{rBC}$ concentrations in the atmosphere. Since the fraction of cloud droplets sampled by the CVI was less than $100 \%$, the measured activated fractions of $\mathrm{rBC}$ are lower limits to the total fraction of $\mathrm{rBC}$ activated during the two cloud events.

To investigate the factors that control the incorporation of rBC into cloud droplets, we determined lower limits to the coating thickness, the total diameter (rBC core and coating), the coating volume, and the coating volume fraction of the $\mathrm{rBC}$ cores incorporated into cloud droplets. Un-coated $\mathrm{rBC}$ particles with diameters $<100 \mathrm{~nm}$ are not expected to be incorporated into the cloud droplets sampled at Mt. Soledad due to the high supersaturations required for nucleation of un-coated $100 \mathrm{~nm}$ rBC particles and the low critical supersaturations often observed for stratocumulus clouds. The coating thicknesses give a qualitative explanation for why we see a relatively large activated fraction of $\mathrm{rBC}$ cores with sizes $<100 \mathrm{~nm}-$ the $\mathrm{rBC}$ cores with sizes $<100 \mathrm{~nm}$ have relatively thick coatings, which increases the overall size of the rBCcontaining particles and provides soluble material for the particle, which can lower the critical supersaturation required for activation. The measurements of the coating volume fraction show the median coating volume fraction was at least 0.9 
for $\mathrm{rBC}$ core diameters ranging from 85 to $95 \mathrm{~nm}$, a result consistent with $\kappa$-Köhler theory. In addition, the measurements suggest that the total diameter ( $\mathrm{rBC}$ core and coating) must be at least $165 \mathrm{~nm}$ in order for $\mathrm{rBC}$ cores with diameters $\geq 85 \mathrm{~nm}$ to be incorporated into cloud droplets. The results also suggest that the total particle diameter (core and coating thickness) is important for determining if $\mathrm{rBC}$ particles are incorporated into the cloud droplets. This finding is consistent with previous work that has shown that particle diameter is important for activation of non-rBC-containing particles (Wang et al., 2008).

\section{The Supplement related to this article is available online at doi:10.5194/acp-15-1367-2015-supplement.}

Acknowledgements. The authors would like to thank D. ToomSauntry, S. Sharma, and A. Sheppard, from Environment Canada, as well as A. Lee and R. Zhou, from the University of Toronto, for their contributions during the campaign and the three anonymous referees for very helpful feedback on the manuscript. The authors are also grateful for funding provided by Environment Canada through the Clean Air Regulatory Agenda, NSERC, NSF (grant AGS1013423), and the FORMAS MACCII project.

Edited by: B. Ervens

\section{References}

Allan, J. D., Delia, A. E., Coe, H., Bower, K. N., Alfarra, M. R., Jimenez, J. L., Middlebrook, A. M., Drewnick, F., Onasch, T. B., Canagaratna, M. R., Jayne, J. T., and Worsnop, D. R.: A generalised method for the extraction of chemically resolved mass spectra from Aerodyne aerosol mass spectrometer data, J. Aerosol Sci., 35, 909-922, doi:10.1016/j.jaerosci.2004.02.007, 2004.

Anderson, T. L., Charlson, R. J., and Covert, D. S.: Calibration of a Counterflow Virtual Impactor at Aerodynamic Diameters from 1 to $15 \mu \mathrm{m}$, Aerosol Sci. Technol., 19, 317-329, 1993.

Andreae, M. O.: Correlation between cloud condensation nuclei concentration and aerosol optical thickness in remote and polluted regions, Atmos. Chem. Phys., 9, 543-556, doi:10.5194/acp-9-543-2009, 2009.

Andreae, M. O. and Rosenfeld, D.: Aerosol cloud precipitation interactions. Part 1. The nature and sources of cloud-active aerosols, Earth-Sci. Rev., 89, 13-41, doi:10.1016/j.earscirev.2008.03.001, 2008.

Bates, T. S., Quinn, P. K., Covert, D. S., Coffman, D. J., Johnson, J. E., and Wiedensohler, A.: Aerosol physical properties and processes in the lower marine boundary layer: a comparison of shipboard sub-micron data from ACE-1 and ACE-2, Tellus B, 52B, 258-272, 2000.

Bates, T. S., Coffman D. J., Covert, D. S., and Quinn, P. K.: Regional marine boundary layer aerosol size distributions in the Indian, Atlantic, and Pacific Oceans: A comparison of INDOEX measurements with ACE-1, ACE-2, and Aerosols99, J. Geophys. Res., 107, 8026, doi:10.1029/2001JD001174, 2002.

Baumgardner, D., Popovicheva, O., Allan, J., Bernardoni, V., Cao, J., Cavalli, F., Cozic, J., Diapouli, E., Eleftheriadis, K., Genberg, P. J., Gonzalez, C., Gysel, M., John, A., Kirchstetter, T. W., Kuhlbusch, T. A. J., Laborde, M., Lack, D., Müller, T., Niessner, R., Petzold, A., Piazzalunga, A., Putaud, J. P., Schwarz, J., Sheridan, P., Subramanian, R., Swietlicki, E., Valli, G., Vecchi, R., and Viana, M.: Soot reference materials for instrument calibration and intercomparisons: a workshop summary with recommendations, Atmos. Meas. Tech., 5, 1869-1887, doi:10.5194/amt-51869-2012, 2012.

Bond, T. C. and Bergstrom, R. W.: Light Absorption by Carbonaceous Particles: An Investigative Review, Aerosol Sci. Technol., 40, 27-67, doi:10.1080/02786820500421521, 2006.

Bond, T. C., Doherty, S. J., Fahey, D. W., Forster, P. M., Berntsen, T., DeAngelo, B. J., Flanner, M. G., Ghan, S., Kärcher, B., Koch, D., Kinne, S., Kondo, Y., Quinn, P. K., Sarofim, M. C., Schultz, M. G., Schulz, M., Venkataraman, C., Zhang, H., Zhang, S., Bellouin, N., Guttikunda, S. K., Hopke, P. K., Jacobson, M. Z., Kaiser, J. W., Klimont, Z., Lohmann, U., Schwarz, J. P., Shindell, D., Storelvmo, T., Warren, S. G., and Zender, C. S.: Bounding the role of black carbon in the climate system: A scientific assessment, J. Geophys. Res.-Atmos., 118, 5380-5552, doi:10.1002/jgrd.50171, 2013.

Chang, R. Y.-W., Slowik, J. G., Shantz, N. C., Vlasenko, A., Liggio, J., Sjostedt, S. J., Leaitch, W. R., and Abbatt, J. P. D.: The hygroscopicity parameter $(\kappa)$ of ambient organic aerosol at a field site subject to biogenic and anthropogenic influences: relationship to degree of aerosol oxidation, Atmos. Chem. Phys., 10, 5047-5064, doi:10.5194/acp-10-5047-2010, 2010.

Cooke, W., Jennings, S. G., and Spain, T. G.: Black carbon measurements at Mace Head, 1989-1996, J. Geophys. Res., 102, 19891996, doi:10.1029/97JD01430, 1997.

Cozic, J., Verheggen, B., Mertes, S., Connolly, P., Bower, K., Petzold, A., Baltensperger, U., and Weingartner, E.: Scavenging of black carbon in mixed phase clouds at the high alpine site Jungfraujoch, Atmos. Chem. Phys., 7, 1797-1807, doi:10.5194/acp-7-1797-2007, 2007.

DeCarlo, P. F., Kimmel, J. R., Trimborn, A., Northway, M. J., Jayne, J.T., Jayne, J. T., Aiken, A. C., Gonin, M., Fuhrer, K., Horvath, T., Docherty, K. S., Worsnop, D. R., and Jimenez, J. L.: Fielddeployable, high-resolution, time-of-flight aerosol mass spectrometer, Anal. Chem., 78, 8281-8289, doi:10.1021/ac061249n, 2006.

Draxler, R. R. and Rolph, G. D.: HYSPLIT (HYbrid Single-Particle Langrangian Integrated Trajectory) Model access via NOAA ARL READY Website, NOAA Air Resources Laboratory, Silver Spring, MD, available at: http://ready.arl.noaa.gov/HYSPLIT. php, last access: 4 February 2014, 2013 .

Eugster, W., Burkard, R., Holwerda, F., Scatena, F. N., and Bruijnzeel, L. A.: Sampurno.: Characteristics of fog and fogwater fluxes in a Puerto Rican elfin cloud forest, Agr. Forest Meteorol., 139, 288-306, 2006.

Fierce, L., Riemer, N., and Bond, T. C.: When is cloud condensation nuclei activity sensitive to particle characteristics at emission?, J. Geophys. Res.-Atmos., 118, 13476-13488, doi:10.1002/2013JD020608, 2013. 
Gao, R. S., Schwarz, J. P., Kelly, K. K., Fahey, D. W., Watts, L. A., Thompson, T. L., Spackman, J. R., Slowik, J. G., Cross, E. S., Han, J.-H., Davidovits, P., Onasch, T. B., and Worsnop, D. R.: A Novel Method for Estimating LightScattering Properties of Soot Aerosols Using a Modified SingleParticle Soot Photometer, Aerosol Sci. Technol., 41, 125-135, doi:10.1080/02786820601118398, 2007.

Gieray, R., Wieser, P., Engelhardt, T., Swietlicki, E., Hansson, H.C., Mentes, B., Orsini, D., Martinsson, B., Svenningsson, B., Noone, K. J., and Heintzenbergg, J.: Phase partitioning of aerosol constituents in cloud based on single-particle and bulk analysis, Atmos. Environ., 31, 2491-2502, 1997.

Glantz, P. and Noone, K. J.: A physically-based algorithm for estimating the relationship between aerosol mass and cloud droplet number, Tellus B, 52B, 1216-1231, 2000.

Granat, L., Engström, J. E., Praveen, S., and Rodhe, H.: Light absorbing material (soot) in rainwater and in aerosol particles in the Maldives, J. Geophys. Res., 115, 1-12, doi:10.1029/2009JD013768, 2010.

Gysel, M., Crosier, J., Topping, D. O., Whitehead, J. D., Bower, K. N., Cubison, M. J., Williams, P. I., Flynn, M. J., McFiggans, G. B., and Coe, H.: Closure study between chemical composition and hygroscopic growth of aerosol particles during TORCH2, Atmos. Chem. Phys., 7, 6131-6144, doi:10.5194/acp-7-61312007, 2007.

Gysel, M., Laborde, M., Olfert, J. S., Subramanian, R., and Gröhn, A. J.: Effective density of Aquadag and fullerene soot black carbon reference materials used for SP2 calibration, Atmos. Meas. Tech., 4, 2851-2858, doi:10.5194/amt-4-2851-2011, 2011.

Hallberg, A., Ogren, J. A., Noone, K. J., Heintzenberg, J., Berner, A., Solly, I., Kruisz, C., Reischl, G., Fuzzi, S., Facchini, M. C., Hansson, H.-C., Wiedensohler, A., and Svenningsson, I. B.: Phase partitioning for different aerosol species in fog, Tellus B, 44B, 545-555, 1992.

Hallberg, A., Ogren, J. A., Noone, K. J., Okada, K., Heintzenberg, J., and Svenningsson, I. B.: The influence of aerosol particle composition on cloud droplet formation, J. Atmos. Chem., 19, 153-171, 1994.

Hawkins, L. N., Russell, L. M., Covert, D. S., Quinn, P. K., and Bates, T. S.: Carboxylic acids, sulfates, and organosulfates in processed continental organic aerosol over the southeast Pacific Ocean during VOCALS-REx 2008, J. Geophys. Res., 115, D13201, doi:10.1029/2009JD013276, 2010.

Hersey, S. P., Craven, J. S., Metcalf, A. R., Lin, J., Lathem, T., Suski, K. J., Cahill, J. F., Duong, H. T., Sorooshian, A., Jonsson, H. H., Shiraiwa, M., Zuend, A., Nenes, A., Prather, K. A., Flagan, R. C., and Seinfeld, J. H.: Composition and hygroscopicity of the Los Angeles Aerosol: CalNex, J. Geophys. Res.-Atmos., 118, 30163036, doi:10.1002/jgrd.50307, 2013.

Hitzenberger, R., Berner, A., Kromp, R., Kasper-Giebl, A., Limbeck, A., Tscherwenka, W., and Puxbaum, H.: Black carbon and other species at a high-elevation European site (Mount Sonnblick, $3106 \mathrm{~m}$, Austria): Concentrations and scavenging efficiencies, J. Geophys. Res., 105, 24637-24645, 2000.

Hitzenberger, R., Berner, A., Glebl, H., Drobesch, K., Kasper-Giebl, A., Loeflund, M., Urban, H., and Puxbaum, H.: Black carbon (BC) in alpine aerosols and cloud water - concentrations and scavenging efficiencies, Atmos. Environ., 35, 5135-5141, 2001.
Kasper-Giebl, A., Koch, A., Hitzenberger, R., and Puxbaum, H.: Scavenging efficiency of "aerosol carbon" and sulfate in supercooled clouds at Mt. Sonnblick (3106 m asl, Austria), J. Atmos. Chem., 35, 33-46, 2000.

Laborde, M., Mertes, P., Zieger, P., Dommen, J., Baltensperger, U., and Gysel, M.: Sensitivity of the Single Particle Soot Photometer to different black carbon types, Atmos. Meas. Tech., 5, 10311043, doi:10.5194/amt-5-1031-2012, 2012.

Lance, S., Raatikainen, T., Onasch, T. B., Worsnop, D. R., Yu, X.-Y., Alexander, M. L., Stolzenburg, M. R., McMurry, P. H., Smith, J. N., and Nenes, A.: Aerosol mixing state, hygroscopic growth and cloud activation efficiency during MIRAGE 2006, Atmos. Chem. Phys., 13, 5049-5062, doi:10.5194/acp-13-5049-2013, 2013.

Lathem, T. L., Beyersdorf, A. J., Thornhill, K. L., Winstead, E. L., Cubison, M. J., Hecobian, A., Jimenez, J. L., Weber, R. J., Anderson, B. E., and Nenes, A.: Analysis of CCN activity of Arctic aerosol and Canadian biomass burning during summer 2008, Atmos. Chem. Phys., 13, 2735-2756, doi:10.5194/acp-13-27352013, 2013.

Lide, D. R. (Ed.): CRC Handbook of Chemistry and Physics, 82nd ed., CRC Press, 2001.

Mätzler, C.: MATLAB Functions for Mie Scattering and Absorption Version 1 - Research Report No. 2002-08, available at: http://www.iap.unibe.ch/publications/download/201/en/, 20 October 2014, 2002a.

Mätzler, C.: MATLAB Functions for Mie Scattering and Absorption Version 2 - Research Report No. 2002-11, available at: www. iap.unibe.ch/publications/download/199/en/, 20 October 2014, $2002 b$.

Mei, F., Hayes, P. L., Ortega, A., Taylor, J. W., Allan, J. D., Gilman, J., Kuster, W., de Gouw, J., Jimenez, J. L., and Wang, J.: Droplet activation properties of organic aerosols observed at an urban site during CalNex-LA, J. Geophys. Res.-Atmos., 118, 2903-2917, doi:10.1002/jgrd.50285, 2013

Metcalf, A. R., Craven, J. S., Ensberg, J. J., Brioude, J., Angevine, W., Sorooshian, A., Duong, H. T., Jonsson, H. H., Flagan, R. C., and Seinfeld, J. H.: Black carbon aerosol over the Los Angeles Basin during CalNex, J. Geophys. Res.-Atmos., 117, 1-24, doi:10.1029/2011JD017255, 2012.

Modini, R. L., Frossard, A. A., Ahlm, L., Russell, L.M., Corrigan, C. E., Roberts, G. C., Hawkins, L. N., Schroder, J. C., Bertram, A. K., Zhao, R., Lee, A. K. Y., Abbatt, J. P. D., Lin, J., Nenes, A., Wang, Z., Wonaschütz, A., Sorooshian, A., Noone, K. J., Jonsson, H., Seinfeld, J. H., Toom-Sauntry, D., Macdonald, A. M., and Leaitch, W. R.: Sea-spray-areosol-cloud interactions off the coast of California, in preparation, 2015.

Moore, R. H., Cerully, K., Bahreini, R., Brock, C. A., Middlebrook, A. M., and Nenes, A.: Hygroscopicity and composition of California CCN during summer 2010, J. Geophys. Res.-Atmos., 117, 1-14, doi:10.1029/2011JD017352, 2012.

Moteki, N. and Kondo, Y.: Effects of Mixing State on Black Carbon Measurements by Laser-Induced Incandescence, Aerosol Sci Technol., 41, 398-417, doi:10.1080/02786820701199728, 2007.

Moteki, N., Kondo, Y., Takegawa, N., and Nakamura, S.: Directional dependence of thermal emission from nonspherical carbon particles, J. Aerosol Sci., 40, 790-801, doi:10.1016/j.jaerosci.2009.05.003, 2009.

Moteki, N., Kondo, Y., and Nakamura, S.: Method to measure refractive indices of small nonspherical particles: Appli- 
cation to black carbon particles, J. Aerosol Sci., 41, 513-521, doi:10.1016/j.jaerosci.2010.02.013, 2010.

Noone, K. J., Ogren, J. A., Heintzenberg, J., Charlson, R. J., and Covert, D. S.: Design and Calibration of a Counterflow Virtual Impactor for Sampling of Atmospheric Fog and Cloud Droplets, Aerosol Sci. Technol., 8, 235-244, 1988.

O'Dowd, C., Becker, E., and Kulmala, M.: Mid-latitude NorthAtlantic aerosol characteristics in clean and polluted air, Atmos. Res., 58, 167-185, 2001.

Ovadnevaite, J., Ceburnis, D., Canagaratna, M., Berresheim, H., Bialek, J., Martucci, G., Worsnop, D. R., and O'Dowd, C.: On the effect of wind speed on submicron sea salt mass concentrations and source fluxes, J. Geophys. Res., 117, 1-11, doi:10.1029/2011JD017379, 2012.

Pekour, M. S. and Cziczo, D. J.: Wake capture, particle breakup, and other artifacts associated with counterflow virtual impaction, Aerosol Sci. Technol., 45, 758-764, doi:10.1080/02786826.2011.558942, 2011.

Petters, M. D. and Kreidenweis, S. M.: A single parameter representation of hygroscopic growth and cloud condensation nucleus activity, Atmos. Chem. Phys., 7, 1961-1971, doi:10.5194/acp-71961-2007, 2007.

Pirjola, L. and O'Dowd, C.: Can new particle formation occur in the clean marine boundary layer?, J. Geophys. Res., 105, 2653126546, 2000.

Pratt, K. A., Heymsfield, A. J., Twohy, C. H., Murphy, S. M., DeMott, P. J., Hudson, J. G., Subramanian, R., Wang, Z., Seinfeld, J. H., and Prather, K. A.: In Situ Chemical Characterization of Aged Biomass-Burning Aerosols Impacting Cold Wave Clouds, J. Atmos. Sci., 67, 2451-2468, doi:10.1175/2010JAS3330.1, 2010.

Riemer, N., West, M., Zaveri, R., and Easter, R.: Estimating black carbon aging time-scales with a particle-resolved aerosol model, J. Aerosol Sci., 41, 143-158, doi:10.1016/j.jaerosci.2009.08.009, 2010.

Rolph, G. D.: Real-time Environmental Application and Display sYstem (READY) Website. NOAA Air Resources Laboratory, Silver Spring, MD., available at: http//ready.arl.noaa.gov, 4 February 2014, 2013.

Rose, D., Gunthe, S. S., Mikhailov, E., Frank, G. P., Dusek, U., Andreae, M. O., and Pöschl, U.: Calibration and measurement uncertainties of a continuous-flow cloud condensation nuclei counter (DMT-CCNC): $\mathrm{CCN}$ activation of ammonium sulfate and sodium chloride aerosol particles in theory and experiment, Atmos. Chem. Phys., 8, 1153-1179, doi:10.5194/acp-8-11532008, 2008.

Rose, D., Nowak, A., Achtert, P., Wiedensohler, A., Hu, M., Shao, M., Zhang, Y., Andreae, M. O., and Pöschl, U.: Cloud condensation nuclei in polluted air and biomass burning smoke near the mega-city Guangzhou, China - Part 1: Size-resolved measurements and implications for the modeling of aerosol particle hygroscopicity and CCN activity, Atmos. Chem. Phys., 10, 33653383, doi:10.5194/acp-10-3365-2010, 2010.

Schwarz, J. P., Gao, R. S., Fahey, D. W., Thomson, D. S., Watts, L. A., Wilson, J. C., Reeves, J. M., Darbeheshti, M., Baumgardner, D. G., Kok, G. L., Chung, S. H., Schulz, M., Hendricks, J., Lauer, A., Kärcher, B., Slowik, J. G., Rosenlof, K. H., Thompson, T. L., Langford, a. O., Loewenstein, M., and Aikin, K. C.: Single-particle measurements of midlatitude black carbon and light-scattering aerosols from the boundary layer to the lower stratosphere, J. Geophys. Res., 111, 1-15, doi:10.1029/2006JD007076, 2006.

Schwarz, J. P., Gao, R. S., Spackman, J. R., Watts, L. A., Thomson, D. S., Fahey, D. W., Ryerson, T. B., Peischl, J., Holloway, J. S., Trainer, M., Frost, G. J., Baynard, T., Lack, D. A., de Gouw, J. A., Warneke, C., and Del Negro, L. A.: Measurement of the mixing state, mass, and optical size of individual black carbon particles in urban and biomass burning emissions, Geophys. Res. Lett., 35, L13810, doi:10.1029/2008GL033968, 2008a.

Schwarz, J. P., Spackman, J. R., Fahey, D. W., Gao, R. S., Lohmann, U., Stier, P., Watts, L. A., Thomson, D. S., Lack, D. A., Pfister, L., Mahoney, M. J., Baumgardner, D., Wilson, J. C., and Reeves, J. M.: Coatings and their enhancement of black carbon light absorption in the tropical atmosphere, J. Geophys. Res., 113, 1-10, doi:10.1029/2007JD009042, 2008b.

Schwarz, J. P., Spackman, J. R., Gao, R. S., Perring, A. E., Cross, E., Onasch, T. B., Ahern, A., Wrobel, W., Davidovits, P., Olfert, J., Dubey, M. K., Mazzoleni, C., and Fahey, D. W.: The Detection Efficiency of the Single Particle Soot Photometer, Aerosol Sci. Technol., 44, 612-628, doi:10.1080/02786826.2010.481298, 2010.

Schwarzenboeck, A.: Cut size minimization and cloud element break-up in a ground-based CVI, 31, 477-489, 2000.

Sedlacek, A. J., Lewis, E. R., Kleinman, L., Xu, J., and Zhang, Q.: Determination of and evidence for non-core-shell structure of particles containing black carbon using the Single-Particle Soot Photometer (SP2), Geophys. Res. Lett., 39, L06802, doi:10.1029/2012GL050905, 2012.

Sellegri, K., Laj, P., Dupuy, R., Legrand, M., Preunkert, S., and Putaud, J.-P.: Size-dependent scavenging efficiencies of multicomponent atmospheric aerosols in clouds, J. Geophys. Res., 108, 4334, doi:10.1029/2002JD002749, 2003.

Shank, L. M., Howell, S., Clarke, A. D., Freitag, S., Brekhovskikh, V., Kapustin, V., McNaughton, C., Campos, T., and Wood, R.: Organic matter and non-refractory aerosol over the remote Southeast Pacific: oceanic and combustion sources, Atmos. Chem. Phys., 12, 557-576, doi:10.5194/acp-12-557-2012, 2012.

Shantz, N. C., Leaitch, W. R., Phinney, L., Mozurkewich, M., and Toom-Sauntry, D.: The effect of organic compounds on the growth rate of cloud droplets in marine and forest settings, Atmos. Chem. Phys., 8, 5869-5887, doi:10.5194/acp-8-5869-2008, 2008.

Spiegel, J. K., Zieger, P., Bukowiecki, N., Hammer, E., Weingartner, E., and Eugster, W.: Evaluating the capabilities and uncertainties of droplet measurements for the fog droplet spectrometer (FM-100), Atmos. Meas. Tech., 5, 2237-2260, doi:10.5194/amt5-2237-2012, 2012.

Stephens, M., Turner, N., and Sandberg, J.: Particle identification by laser-induced incandescence in a solid-state laser cavity, Appl. Opt., 42, 3726-3736, 2003.

Subramanian, R., Kok, G. L., Baumgardner, D., Clarke, A., Shinozuka, Y., Campos, T. L., Heizer, C. G., Stephens, B. B., de Foy, B., Voss, P. B., and Zaveri, R. A.: Black carbon over Mexico: the effect of atmospheric transport on mixing state, mass absorption cross-section, and BC/CO ratios, Atmos. Chem. Phys., 10, 219 237, doi:10.5194/acp-10-219-2010, 2010.

Targino, A. C., Noone, K. J., Drewnick, F., Schneider, J., Krejci, R., Olivares, G., Hings, S., and Borrmann, S.: Microphysical and 
chemical characteristics of cloud droplet residuals and interstitial particles in continental stratocumulus clouds, Atmos. Res., 86, 225-240, doi:10.1016/j.atmosres.2007.05.001, 2007.

Taylor, J. W., Allan, J. D., Liu, D., Flynn, M., Weber, R., Zhang, X., Lefer, B. L., Grossberg, N., Flynn, J., and Coe, H.: Assessment of the sensitivity of core/shell parameters derived using the singleparticle soot photometer to density and refractive index, Atmos. Meas. Tech. Discuss., 7, 5491-5532, doi:10.5194/amtd-7-54912014, 2014.

Twohy, C. H., Petters, M. D., Snider, J. R., Stevens, B., Tahnk, W., Wetzel, M., Russell, L. M., and Burnet, F.: Evaluation of the aerosol indirect effect in marine stratocumulus clouds: Droplet number, size, liquid water path, and radiative impact, J. Geophys. Res., 110, 1-16, doi:10.1029/2004JD005116, 2005.

Vidaurre, G., Hallett, J., and Rogers, D. C.: Airborne Measurement of Liquid and Total Water Content, J. Atmos. Ocean. Technol., 28, 1088-1103, 2011.

von der Weiden, S.-L., Drewnick, F., and Borrmann, S.: Particle Loss Calculator - a new software tool for the assessment of the performance of aerosol inlet systems, Atmos. Meas. Tech., 2, 479-494, doi:10.5194/amt-2-479-2009, 2009.

Wang, J., Lee, Y.-N., Daum, P. H., Jayne, J., and Alexander, M. L.: Effects of aerosol organics on cloud condensation nucleus $(\mathrm{CCN})$ concentration and first indirect aerosol effect, Atmos. Chem. Phys., 8, 6325-6339, doi:10.5194/acp-8-6325-2008, 2008.
Wang, Q., Jacob, D. J., Spackman, J. R., Perring, A. E., Schwarz, J. P., Moteki, N., Marais, E. A., Ge, C., Wang, J., and Barrett, S. R. H.: Global budget and radiative forcing of black carbon aerosol: Constraints from pole-to-pole (HIPPO) observations across the Pacific, J. Geophys. Res.-Atmos., 119, 195-206, doi:10.1002/2013JD020824, 2014.

Wu, Z. J., Poulain, L., Henning, S., Dieckmann, K., Birmili, W., Merkel, M., van Pinxteren, D., Spindler, G., Müller, K., Stratmann, F., Herrmann, H., and Wiedensohler, A.: Relating particle hygroscopicity and $\mathrm{CCN}$ activity to chemical composition during the HCCT-2010 field campaign, Atmos. Chem. Phys., 13, 79837996, doi:10.5194/acp-13-7983-2013, 2013.

Zhao, R., Lee, A. K. Y., Wentzell, J. J. B., Mcdonald, A. M., ToomSauntry, D., Leaitch, W. R., Modini, R. L., Corrigan, A. L., Russell, L. M., Noone, K. J., Schroder, J. C., Bertram, A. K., Hawkins, L. N., Abbatt, J. P. D., and Liggio, J.: Cloud partitioning of isocyanic acid (HNCO) and evidence of secondary source of HNCO in ambient air, Geophys. Res. Lett., 41, 6962-6969, doi::10.1002/2014GL061112, 2014. 